\title{
1 Social homogamy, early industrialization, and marriage restrictions in 2 the canton of Lucerne, Switzerland, 1834-75
}

\section{Simon Seiler}

4 Institute of Sociology, University of Bern, Bern, Switzerland

5 Fabrikstrasse 8, CH-3012 Bern, Switzerland; +41 (0)31 6314846 (telephone);

$6 \quad$ simon.seiler@soz.unibe.ch

8 Acknowledgements

9 My thanks are due to Ineke Maas and Marco H.D. van Leeuwen and two anonymous reviewers

10 for their valuable thoughts and comments on this study. Earlier versions of this article were

11 presented in the session entitled "Social Homogamy in Comparative Perspective" of the

12 European Social Science History Conference in Valencia (March 30-April 2, 2016), and in the

13 MaSS seminar of the Department of Social Sciences at Utrecht University (October 19, 2016). I

14 wish to thank the participants for their helpful and detailed comments. Finally, I would like to

15 thank Norbert Furrer and Gaudenz Welti for their important assistance during the collection of

16 the data used in this article.

18 Funding

19 This article is part of $\mathrm{PhD}$ project "Perspectives on Social Mobility in $19^{\text {th }}$ and $20^{\text {th }}$ Century

20 Switzerland", funded by the Swiss National Science Foundation within the funding scheme

21 "Doc.CH" under grant number 155473. Establishing the datasets for the $19^{\text {th }}$ century was made 22 possible by complementary funding from the IMG Foundation, Bern.

24 Word counts:

25 Abstract: 263 Words

26 Article (including notes, excluding references): 10,199

27 Article (excluding notes and references): 9,513 


\section{Social homogamy, early industrialization, and marriage restrictions in 2 the canton of Lucerne, Switzerland, 1834-75}

The modernization thesis assumes decreasing relevance of an individual's family background to various aspects of modern and industrial life, which should also translate into a decrease in marital homogamy by social origin. However, longterm historical processes are rarely unidimensional and monotonous, and multiple processes may mask one another. For example, although previous research provides evidence for a relationship between degree of industrialization and homogamy, most studies have found no clear time trend. Using new data $(N=1,499)$ for the Swiss canton of Lucerne from the $19^{\text {th }}$ century, data which include occupational status of fathers (HISCAM), this article approaches from two angles the problem of confounding processes. First, changes in marriage restrictions during the period of study are identified as a significant and unmeasurable confounder. Because the timespan of reinforced marriage restriction is known, time trends in homogamy can be modelled to allow partial disentanglement of the effects on homogamy of modernization and marriage restrictions. Second, although there were few direct measures of modernization taken in Lucerne during that period, two parish level measures can be identified: connection to the railway system, and the proportion of factory workers in the population. Using multilevel models with constraint simultaneous equations for both possible directions of explanation, the analyses reveal homogamy effects of industrialization and marriage restrictions that differ by social strata. In the lower and middle strata, homogamy was stronger in rural areas than in the city of Lucerne, while the opposite was true for the upper stratum. Furthermore, homogamy increased with rising levels of marriage restrictions but in lower and middle strata it decreased with industrialization.

Keywords: social homogamy; industrialization; marriage restrictions; $19^{\text {th }}$ century; Switzerland

Although selection of a spouse is a very personal decision for both partners, it is always shaped by personal as well as structural factors, such as education, social origin, or the opportunity structure of a given context. One result of such assortative mating is homogamy, by which is meant that on average people choose partners who are in many 
1 ways more similar to themselves than to randomly chosen others (Kalmijn, 1998;

2 Schwartz, 2013) and in contemporary western societies the most important of those

3 characteristics might be achieved personal characteristics like education (Blossfeld,

4 2009; Kalmijn, 1991a). That would be in line with one of the central promises of

5 modernization, which is that it will lead to open, socially fluid societies which ignore

6 purely ascribed characteristics like social origin (Maas \& van Leeuwen, 2016) although

7 that promise has been questioned by recent and broadly discussed research on rising

8 economic inequality. Authors like Piketty (2013) or Milanović (2016) have suggested

9 that growing inequality and the increasing importance of capital returns could lead to a

10 situation similar to that at the end of the $19^{\text {th }}$ century when family resources mattered

11 more than education or achievements. Such a development would be in complete

12 opposition to the prediction of liberal economic theorists like Kuznets (1955), or Kerr,

13 Dunlop, Harbison, and Myers (1960) and Treiman (1970) who were proponents of the

14 modernization thesis. They assumed decreasing inequality, and continual reduction of

15 the importance to status allocation of ascribed characteristics like social origin.

16 In this article I shall analyse homogamy by reference to the social status of

17 parents. The underlying assumption is that a strong link between social origin and a

18 variety of aspects of the lives of brides and grooms means that we may presuppose

19 strong homogamy by parental status. That in turn - all other things being equal - will

20 lead to a decrease in the general importance of social origin in a given society and

21 results in declining influence of social origin on selection of spouses (cf., Kalmijn,

22 1991b; Zijdeman \& Maas, 2010). Therefore, analysing homogamy in respect of social

23 origin (subsequently abbreviated to "social homogamy" or simply "homogamy") is one

24 possible way to study the importance of social origin for individual lives. Applied to an

25 area and period of industrialization, analysing social homogamy also provides a test for 
1 the "logic of the industrialization process" (Kerr et al., 1960, p. 34): the assumption that

2 industrialization is the most important driver for the decreasing importance of social

3 origin. An analysis of social homogamy might therefore complement other analyses of

4 social origin effects in such periods, such as studies of intergenerational social mobility

5 using historical data (Lippényi, Maas, \& van Leeuwen, 2015; van Leeuwen, Maas,

6 Rébaudo, \& Pélissier, 2016; Zijdeman, 2009). More generally it also adds to the debate

7 inspired by the writings of Le Play (e.g., 1877-79) about whether industrialization and

8 urbanization have changed the organization of the family (Janssens, 1986; Laslett, 1974;

9 Puschmann \& Solli, 2014).

10 While homogamy might have changed according to the modernization thesis,

11 modernization is unlikely to be the only relevant factor affecting changes in homogamy

12 over time. For example, not only can the question of who marries whom be related to

13 social origin, but so can the question of who gets married in the first place. The

14 relationship itself, too, may change over time. As a reaction to $19^{\text {th }}$ century pauperism

15 many local and central authorities in Switzerland and other German speaking areas

16 reinforced existing marriage restrictions with the aim of preventing the poor from

17 proliferating (Head-König, 1993; Mantl, 1999; Matz, 1980). By placing emphasis on

18 inherited property rather than on personal income, strong marriage restrictions helped to

19 maintain unequal access to marriage (Mantl, 1999). In other words, the strengthening of

20 marriage restrictions may have counteracted the general decreasing importance of social

21 origin over the course of modernization. It is worth noting here that modernization and

22 increasing marriage restrictions were not independent trends. For many commentators

23 of the $19^{\text {th }}$ century, the widespread pauperism was caused by industrialization (Mantl,

24 1999) - which meant that stricter marriage restrictions were an indirect reaction to

25 modernization. 
Using new data drawn from $19^{\text {th }}$ century canton of Lucerne this article aims to

2 analyse the combined effects of industrialization and marriage restrictions. Lucerne

3 operated some of Switzerland's most severe marriage restrictions (Head-König, 1993)

4 and while it remained primarily agrarian certain areas saw unmistakeable

5 industrialization (Dubler, 1983; Schnider, 1996). Furthermore, Lucerne is one of the

6 few cantons for which sources are available that systematically include the occupations

7 of the fathers of both spouses in a marriage. For the period $1834-75$ the central

8 authorities of Lucerne took control of the church records and required parish priests to

9 include in marriage registers information about occupations (Gössi \& Huber, 2001). The

10 period covers the early industrialization of certain areas of the canton but coincided too

11 with a peak in marriage restrictions around 1865, whereafter they were relaxed again

12 toward the end of the period (Bossard-Borner, 2008, pp. 532-550). These features of the

13 data allow it at least partly to disentangle the effects of industrialization and changing

14 marriage restrictions, even though only indirect measurements, such as illegitimacy

15 rates, are available that do not allow estimating the severity of the marriage restrictions

16 on the local level. However, two direct measurements of modernization are available at

17 the level of individual parishes and they enrich the data. A variable on the presence of

18 railway stations measures the availability of modern means of transport, and the

19 proportion of factory workers serves as a proxy for the level of industrialization of a

20 given parish. Although relatively crude, both those measures complement the indirect

21 test of modernization effects using time trends. That is of special significance because

22 most previous studies found no clear time trends (Bull, 2005; Dribe \& Lundh, 2009;

23 Maas \& van Leeuwen, 2005; van Leeuwen \& Maas, 2002), but were able to identify the

24 effects of more directly measured industrialization (Maas, van Leeuwen, Pélissier, \&

25 Rébaudo, 2011; Zijdeman \& Maas, 2010). 
2 scarce and the few existing studies examine only the two Protestant cities of Winterthur

3 (Schumacher \& Lorenzetti, 2005) and Geneva (Widmer, 1993). This analysis of new

4 data from a catholic and predominantly agrarian canton like Lucerne therefore addresses

5 an area of which nothing was previously known about homogamy. Consequently, one

6 of this article's aims is to describe the homogamy by social origin seen in the city of

7 Lucerne and the rural area around it, and to trace changes to it over the 40 years of the

8 observed period (1834-75). However, the article's main goal remains to derive and test

9 hypotheses about how social homogamy changed with modernization, and how the

10 process was affected by changing levels of marriage restriction in the canton.

11 The remainder of this article is organized as follows. The next section presents

12 the background to the $19^{\text {th }}$ century canton of Lucerne thereby providing the context for

13 the marriages and marriage registers analysed in the article. Description of the historical

14 background is followed by the theoretical considerations from which the hypotheses are

15 derived and by a description of the data, measurements and statistical models that

16 allowed us to test the hypotheses. Finally, the results are presented and discussed.

\section{$17 \quad 1$ The canton of Lucerne and the sources}

18 Lucerne is a medium sized canton in central Switzerland (see map at Figure 1) and

19 throughout the $19^{\text {th }}$ century remained a predominantly agrarian canton with the city of

20 Lucerne its undisputed capital. At the beginning of the $19^{\text {th }}$ century the canton was

21 divided into three agrarian areas, with the partly alpine south defined by animal

22 husbandry and production of milk and cheese, while the hilly central and flatter

23 northern region devoted to the cultivation of grain, although the two areas differed in

24 their modes of production. In central Lucerne canton field crops and fodder for small 
1 livestock were produced on separate farms on mostly private land. In the northern areas

2 by contrast, production was still organized using the three-field system which required

3 collective farming ('Flurzwang'), as individual farmers' properties were dispersed over

4 all three fields (Bossard-Borner, 1998, pp. 38-42; Dubler, 1983, pp. 71-95).

5

6 This 'Flurzwang' and the requirement to deliver tithes in the form of a prescribed

7 composition of field crops, had constrained agricultural innovation during the $18^{\text {th }}$

8 century until change came during the first half of the $19^{\text {th }}$ century. Then, over the rest of

9 the century agriculture in Lucerne canton saw strong modernization as municipalities

10 were allowed to privatize parts of their commons, action which often led to improved

11 situations for small farmers who could now increase production above subsistence level

12 (Bossard-Borner, 1998, pp. 309-312). In addition the optional tithe redemption,

13 together with the abolition of the 'Flurzwang', allowed wealthy farmers to change to

14 more lucrative animal husbandry which increased their cash crops and in turn laid the

15 foundation for the mechanization of farming towards the end of the $19^{\text {th }}$ century. Those

16 factors were the precondition for rational and market-oriented agriculture which

17 increased yields enormously (Bossard-Borner, 1998, pp. 306-314; Dubler, 1983,

18 pp. 95-113). other sectors and factory industrialization took longer to take off. There were areas with growing industry, mainly around the capital and in the north eastern Wiggerthal (Bossard-Borner, 1998; Dubler, 1983). Before 1850 there were only a small number of

23 factory workers in the canton, many of them employed in factories processing

24 horsehair, a sector that disappeared sometime in the half of the $19^{\text {th }}$ century. To a certain extent however, by the time of the second factory census in 1877 , which was shortly 
1 after the period analysed in this article, the situation had changed. Although the overall

2 proportion of factory workers remained low and the canton's industrialized area was

3 roughly the same as it had been in 1850 , industry became a significant factor in those

4 few municipalities that could boast factories. Around Lucerne city for example, the

5 proportion of factory workers approached $10 \%$ of the population as steel production,

6 machine construction, and above all the textile industry had become relevant sectors

7 (Schnider, 1996, pp. 41-56). Industrialization gained pace as some parts of the canton

8 were connected to the Swiss railway system (see Figure 1) which also enabled the rise

9 of Lucerne as an important tourist destination (Dubler, 1983; Schnider, 1996).

10 The development of Lucerne as a modern tourist resort was also a significant

11 accelerator of the growth of the city's population, which was driven mainly by

12 immigration, with female domestic workers featuring prominently among the

13 predominantly intra-cantonal immigrants (Balthasar, 1988; Head-König, 1999).

14 Therefore, migration to the city of Lucerne consisted not only of short-term movement,

15 for example that of young people working in the city but returning when somewhat

16 older, (see for example Ehmer, 2011), but also of many people who remained in the

17 city. Migration to Lucerne city and its surroundings continued even after economic

18 growth slowed down at the end of the 1840 s, so that now unemployed migrants visibly

19 added to the growing number of paupers during those years. In the middle years of the

20 century the canton experienced economic tension due not only to growing competition

21 from more industrialized areas but because of bad weather too which led to high prices

22 of bread and potatoes (Bossard-Borner, 2008, pp. 532-541). This difficult situation was

23 accentuated by a short war which preceded the partially forcible and conflict-laden

24 integration into the newly-founded liberal federal state of Switzerland in 1848 (Bossard-

25 Borner, 2008, 2010). 
By contrast with other cantons Lucerne did not outsource the resulting burden of

2 poor relief by actively supporting emigration overseas. As in other German-speaking

3 areas (Mantl, 1999; Matz, 1980) the authorities tried to forbid reproduction among the

4 poor by strengthening existing marriage restrictions. That contributed to a marriage

5 pattern in Lucerne that perfectly fits the "European Marriage Pattern" as depicted by

6 Hajnal (1965, p. 101) namely "a high age at marriage and a high proportion of people

7 who never marry at all". ${ }^{1}$ Marriage restrictions were imposed on men who had either

8 relied on poor relief after the age of 16 and had not repaid it, or who lacked the means

9 the local authorities considered necessary to raise offspring in an "honest way" (Kanton

10 Luzern, 1831-1840, pp. 261-270, cited in Bossard-Borner, 2008, p. 545). The central

11 authorities backed up their rigid restrictions. Their judicial response to appeal against

12 refusal of permission to marry was very restrictive until 1857 , when as a result of the

13 improved economic situation it suddenly became more liberal (Bossard-Borner, 2008,

14 p. 545). The change in legal practice was reinforced by the fact that during the

15 economic crisis, high marriage fees had become unaffordable to more and more people.

1 To the best of my knowledge, no comprehensive demographic statistic exists for the $19^{\text {th }}$ century canton of Lucerne. However, in the sample used for this study the median age at first marriage of women and men was 27.0 and 31.9, respectively. From an additional sample collected from the death registers of five parishes (Altishofen, Entlebuch, Ettiswil, Hitzkirch, Kriens, and Lucerne) it can be estimated that about $20 \%$ of men survived beyond the age of 45 remained unmarried. That corresponds to the number cited by Hajnal (1953, p. 85) for Switzerland and falls in about the middle of the range for the Austrian alpine region found by Ortmayr (1995); data based on: StALU, FA 29/8, 51, 64, 91, 118, 119; KZ 33, 35, 37, 39 , 41. 
1 One consequence was that the illegitimacy rate which had been slowly increasing

2 during the first half of the $19^{\text {th }}$ century, rose quickly after 1845 until it peaked at about

$315 \%$ in 1864, before falling back to about 5\% at the beginning of the 1870s (Bossard-

4 Borner, 1998, pp. 297-306, 2008, pp. 532-550; Head-König, 1993). The interplay of

5 economic and political factors thus led to reinforced demographic characteristics of low

6 marriage and high illegitimacy rates in the $19^{\text {th }}$ century canton of Lucerne. For the

7 present study, those demographic characteristics had three consequences:

8 (1) The marriage restrictions were successful insofar as married individuals indeed

(2) The high illegitimacy rate may point to existing relationships out of wedlock. In many cases however, multiple fathers were involved when women had multiple illegitimate children (Kok \& Leinarte, 2015). In other words, a high illegitimacy rate might suggest a high rate of unmarried couples although not necessarily so. As there is no systematic source for that time for unmarried couples, analysis of homogamy is therefore necessarily restricted to marital homogamy.

(3) Increased marriage restrictions in the middle of the $19^{\text {th }}$ century might have affected homogamy by social origin (see next section for arguments), which might in turn have disturbed trends caused by processes such as industrialization. According to the literature however marriage restrictions, while strong in the middle of the century, were relatively weak at the beginning

\footnotetext{
2 Source: see note 1.
} 
5 Because of the relatively high proportion of individuals who did not marry at all,

6 marriage registers are a selective source. Nevertheless they are the only available source

7 for the large scale study of parental homogamy in $19^{\text {th }}$ century Lucerne. They are even

8 an exceptional source, as most marriage registers in Switzerland do not include

9 occupational titles of parents in any systematic way. That is true for the canton of

10 Lucerne too, but not for the period 1834-75 investigated in this article. During a liberal

11 intermezzo of 1831-41 the state of Lucerne decided to take control of parish registers.

12 Pre-printed tables were issued for priests to fill in, and the law defined how state

13 officials were required to monitor the maintenance of the registers. ${ }^{3}$ In comparison with

14 other areas and periods then, for this period the canton of Lucerne offers marriage

15 registers of exceptional quality, as the information in them is not only rich but was

16 consistently and systematically collected. Their data therefore allows analysis of

17 processes of social stratification, including homogamy by social origin.

\section{Theoretical considerations and hypotheses}

19 To explain changes in homogamy by parent's social status two basic theoretical

20 questions must be addressed. First, why such homogamy can be expected in the first

3 The corresponding decrees can be found at the beginning of each of the books. For this project we used the copies maintained by a municipality official and kept by the State Archives of Lucerne: StALU, A 975 and KZ 23-27, 54-56; cf.: Gössi and Huber (2001). 
1 place And why the extent of homogamy may be assumed to change.

A useful framework for the analysis of spouse selection and the factors driving

3 homogamy is the concept of the "marriage market". In a marriage market men and

4 women seek partners according to their individual preferences but face constrained

5 opportunities (Becker, 1973; Goode, 1964; Schwartz, 2013). Preferences and constraints

6 alike can then lead to social homogamy, as the of actors in the marriage markets tend to

7 favour status maintenance (Boudon, 1974), and to wish to maximize the socioeconomic

8 resources of a future family and to prefer a partner with whom they share at least some

9 cultural values (Kalmijn, 1998). The preferences for similarity and for more resources

10 both lead to homogamy, as if both partners want more of the same and neither wishes to

11 marry down, "everyone ends up with someone roughly similar to themselves"

12 (Schwartz, 2013, p. 453). Of course, "everyone" is an exaggeration, as few will be able

13 to satisfy all their preferences so in order to satisfy certain of them they may reduce

14 their expectations in respect of others. That provides room for exchange; for example a

15 relatively aesthetically unattractive but influential person might be able to marry an

16 uneducated but wealthy partner (cf., Merton, 1941), a process which can explain a

17 mating process with a heterogamous outcome. However, if it make sense to pool the

18 resources of both partners, with resources seen as complements, not substitutes, the

19 resulting partnership will nevertheless tend to be homogamous (Becker, 1973; Edwards,

20 1969). In other words, if both partners value a particular resource, then having more of

21 it (all else being equal) will improve the chances of mating with someone who

22 possesses the same resource.

\subsection{Modernization thesis: the changing importance of social origin}

24 My intent in this article is to analyse homogamy by the status of the parents of a bridal 
1 couple. Homogamy in that respect can exist only if the resources of bride and groom are

2 linked to those of their parents. In other words, homogamy by social origin is a

3 consequence of the association between the particular status of individuals and that of

4 their parents. It is here that the modernization thesis comes into play.

In the literature on social inequality and stratification the term "modernization

6 thesis" usually refers to a construct based on the writings of Kerr et al. (1960), Parsons

7 (e.g. 1960), and other North American social scientists of the $20^{\text {th }}$ century (cf., Erikson

$8 \&$ Goldthorpe, 1992, p. 3). In other words it is based on the concept of modernization in

9 its "classical" form that took shape in the 1950s. In that view "modernization" is a

10 combination of unidirectional processes mutually reinforcing each other, namely

11 industrialization, democratization, bureaucratization, rationalization, and secularization

12 (Mergel, 2012). The modernization thesis assumes that the change from a pre-industrial

13 to an industrial society was quite fundamental and changed many aspects of life. While

14 many aspects of it have been criticized (e.g., Tipps, 1973), the modernization thesis has

15 created influential hypotheses in research on social stratification (Hout \& DiPrete,

16 2006). In that respect the modernization thesis states that social origin loses its

17 importance in the allocation of social positions. More specifically, modernization is

18 thought to change the process of status attainment, for while the thesis assumes that in

19 traditional societies the direct link between parent's and child's status is dominant, it

20 presumes that in modern societies an indirect path via education will be the main path

21 connecting the status of parents and children. However the indirect path will not

22 completely replace the direct one, which results in a weakening link between the

23 generations (Blau \& Duncan, 1967; Treiman, 1970).

24 Following Treiman's (1970) restatement of the modernization thesis, structural

25 changes caused by industrialization result in reduction of the direct effect of social 
1 origin on an individual's social position. First, the reduction of the proportion of the

2 labour force engaged in agriculture on the one hand and on the other the creation of new

3 jobs following technological change and specialization, reduces too the number of jobs

4 for which skills developed by assisting parents are beneficial (Knigge, Maas, van

5 Leeuwen, \& Mandemakers, 2014; Lipset \& Zetterberg, 1959, pp. 57-60). Second, the

6 increasing size of enterprises brings with it rationalization and bureaucratization of

7 production. Rather than relying on ascribed characteristics like social origin, employers

8 therefore increasingly consider such things as achievements in formal education, for

9 such characteristics are more relevant to an estimation of likely productivity (Treiman,

10 1970). Together, such changes make it more difficult to use existing socioeconomic

11 resources directly to grant status maintenance of the succeeding generations.

12 Conversely, those changes ought to be expected to open formerly closed social

13 positions to individuals less well endowed with resources of social origin. Furthermore,

14 the modernization thesis predicts that political, social, and cultural resources will be

15 available to more people. In that view democratization improves the ability of the

16 disadvantaged classes to profit from the economic growth generated by industrialization

17 (Simpson, 1990). Furthermore, educational expansion not only provides the population

18 with the knowledge and skills necessary for newly created occupations, but also creates

19 opportunity for pupils to meet others from different class backgrounds (Kerr et al.,

20 1960, pp. 36-37; van Leeuwen \& Maas, 2005). The emergence of mass media and

21 modern transport supports the development of a common culture and with it the

22 diminution of differences "in attitudes and behavior" by social origin (Treiman, 1970,

23 p. 219).

Taken together, these arguments imply decreasing influence of social origin over

25 the course of modernization, which means too that homogamy should decline in respect 
1 of the social status of parents, for at least two reasons. First, according to the

2 modernization thesis cultural resources depend decreasingly on social origin.

3 Consequently, the cultural similarity preferred by actors on the marriage marked

4 depends less and less on social origin. Second, when actors try to maximize resources

5 for their future family, social origin is of decreasing relevance, because the

6 modernization thesis assumes the weakening of links between an individual's own

7 resources and those of his or her family of origin (Kalmijn, 1991b). That leads us to this

8 first hypothesis: ${ }^{4}$

$9 \quad$ H1: Social homogamy has decreased over time.

10 Because urbanization is viewed as being inherently a driver of modernization (Kuznets,

11 1955; Treiman, 1970), we may expect the importance of social origin to decrease more

12 significantly in cities than in rural areas. Furthermore, the city of Lucerne was more

13 advanced than other parts of the canton in many of the aspects discussed above. It had

14 better schools and provided education to a higher level (Boesch \& Kottmann, 1974;

15 Pfenniger, 1998) offered a wider variety of occupations (Dubler, 1983) and was the

16 home of most of the canton's early entrepreneurs (Bossard-Borner, 1998, p. 318) and of

17 its intellectual elite (Bossard-Borner, 1998, pp. 353-360). It was also the capital, and

18 the canton's central administration and its civil servants were based there (Lischer,

19 2016). That leads us to this second hypothesis based on the modernization thesis:

4 For a similar hypothesis, see Zijdeman and Maas (2010, p. 399). 


\section{$1 \quad 2.2 \quad$ The effect of marriage restrictions}

2 However, for the period of interest to us here the assumption implicitly made by the

3 modernization thesis that "everything else was equal" was clearly not correct. With the

4 marriage restrictions discussed in the last section an important constraint on the

5 selection of spouses changed significantly in the period studied in this article. In the

6 canton of Lucerne the marriage restrictions did not refer directly to the resources of a

7 potential bridal couple's parents, but the authorities considered property rather than

8 income as being important to the ability to raise offspring in an "honest way" (Kanton

9 Luzern, 1831-1840, pp. 261-270, cited in Bossard-Borner, 2008, p. 545). An

10 individual's wealth and property depended much more on his or her parents' resources

11 than on income (Head-König, 1993; Mantl, 1999). Wealth and property inherited from

12 the family of origin therefore became more decisive than other resources which were

13 not directly linked to the family of origin. Conversely, marriage may be expected to be

14 increasingly homogamous in respect of resources related to social origin and less to

15 other characteristics. In short, the marriage restrictions of Lucerne probably increased

16 the importance of the family of origin and, consequently, of homogamy by parental

17 status. If we assume at least some degree of social homogamy, the selection of their

18 spouses by high status individuals should not be substantially affected by marriage

19 restrictions, because high status individuals only rarely chose their partners from the

20 strata affected by marriage restrictions. That leads us to this third hypothesis, which is

21 in two parts:

H3a: Social homogamy increases with marriage restrictions. and middle social origin. 


\section{$1 \quad 2.3 \quad$ Modernization and marriage restrictions combined}

2 It is as impossible perfectly to measure Lucerne's modernization as it is to measure the

3 extent of its marriage restrictions. Nevertheless, we can make certain assumptions about

4 the combination of the effects of the two. Changes to the marriage restrictions it is

5 relatively well known from the literature. Restrictions increased in the first part of the

6 analysed period, reached a peak around 1865 and then declined rapidly (for the exact

7 timing, see the discussion in the next section). By contrast, the typical interpretation of

8 the modernization thesis assumes the modernization process to be more or less linear

9 development over time (cf., Erikson \& Goldthorpe, 1992, p. 21). It is therefore possible

10 to deduce a basic hypothesis for how homogamy changes over time, given the presumed

11 effects of marriage restrictions and modernization.

---Figure 2 about here---

13 Figure 2 shows the combination of the effects of marriage restrictions and

14 modernization. Because marriage restrictions are relevant primarily for individuals of

15 lower and middle social origin, the combination of the two effects does not affect the

16 relationship between modernization and homogamy. Therefore the hypothesis of

17 decreasing homogamy over time (HI) remains directly applicable to individuals from

18 higher social origin, irrespective of any marriage restrictions (Figure 2b). By contrast,

19 for individuals of lower and middle class origin (Figure 2a) the increasing marriage

20 restrictions in the first part of the observed period might be expected to cancel out or

21 even reverse the diluting effect of modernization. For the period after 1865, however,

22 both changes worked in the same direction, so that we may expect a clear decrease in

23 social homogamy for that period. The combined effects on homogamy of marriage

24 restrictions and modernization can therefore be summarized by these hypotheses: 
H4a: Homogamy among individuals of higher social origin decreased over the whole period (1834-75).

$H 4 b$ : Homogamy among individuals of lower and middle social origin stagnated or increased in the period 1834-64.

$H 4 c$ : Homogamy among individuals of lower and middle social origin clearly decreased in the period $1865-75$.

\subsection{Direct measurements of industrialization: the proportion of factory} workers and the presence of railway stations

So far, modernization has been discussed as a latent concept that develops with time.

Because of that its effects can be tested indirectly, in this case by analysing social

homogamy over time. That is in line with how classical studies have tested the

modernization thesis (for example, Breen, 2004; Erikson \& Goldthorpe, 1992).

However, certain more recent studies have identified measurable sub-dimensions of modernization, such as the number of steam engines, expansion of education, and the spread of mass media. The effects of those things on phenomena such as social mobility have been tested (Knigge et al., 2014) and on social homogamy (Zijdeman \& Maas, 2010). Unfortunately, most such modernization measures are not available for the canton of Lucerne, although with two exceptions. We know the availability of rail connections, and we can make a rough estimate of the proportion of factory workers in each of the canton's municipalities.

Two lines of reasoning lead us to expect the availability of a rail connection to be related to the extent of homogamy. First, modern transport may be assumed to contribute to a common culture in which people do not differ greatly by geographical and social origin (Treiman, 1970). In other words, modern means of transport tend to reduce homogamy by social origin by loosening the link between the status of parents and children. A second line of reasoning considers the impact of things like railways at the individual level, for although rarely absolute, geographical boundaries can severely 
1 reduce the likelihood of ever meeting a person from the other side of such a boundary.

2 Modern transport therefore widens the "marriage horizon" of those looking for a spouse

3 and thereby extends the boundaries of the marriage market (van Leeuwen \& Maas,

4 2005). The scope of the marriage market can affect parental homogamy via two paths.

5 First, in wide marriage markets the likelihood of meeting someone of a different social

6 background will be higher than in a narrow market, since living close-by makes a

7 similar social background more likely (Goode, 1964, p. 34; Kalmijn \& Flap, 2001; van

8 Leeuwen \& Maas, 2005, pp. 5-10). Second, a widening of the marriage market over

9 time means that the social contacts of young people tend to go beyond the social

10 networks of their parents, in both geographical and social terms. ${ }^{5}$ Both the lines of

11 reasoning lead to the same hypothesis:

H5: Homogamy was lower in parishes with a rail connection than in parishes without one.

14 The argument for an existing relationship between the proportion of factory workers in

15 a given area and the level of social homogamy follows similar lines of reasoning. A

16 high proportion of factory workers is in the first place a proxy for the industrialization

17 of an area and according to the modernization thesis may be associated with lower

18 overall homogamy by social origin than in areas with a low proportion of factory

19 workers (Treiman, 1970). Furthermore, factories bring together workers of different but

20 low to middle social origin, which might contribute to the fading of the distinctiveness

21 of social origin. Social networks formed in a factory can lay the foundations of future

22 marriage. In mixed industries like the textile industry factory workers might meet a

5 Blossfeld and Timm (2003, pp. 10-11) made this point about educational expansion. 
1 future spouse actually at work (Maas et al., 2011). As individuals of high social origin

2 rarely became factory workers the proportion of factory workers is mainly relevant to

3 individuals of lower or middle social origin.

H6: Homogamy among individuals of low and middle social origin was weaker in parishes with a high proportion of factory workers than in other parishes.

\section{Data, measurements, and methodological approach}

\section{$7 \quad 3.1 \quad$ Data}

8 The dataset used for this study was taken from the marriage registers presented in the

9 first section and has been sampled following a stratified design. Marriages from three

10 strata have been sampled independently: from the city of Lucerne, from parishes with

11 no industry, and from parishes with at least some industry. ${ }^{6}$ We used a two-stage

12 sampling design for the large area with no industry, randomly choosing 25 of 63

13 parishes and then sampling marriages within the selected parishes. The chosen design

14 ensured that each marriage in the area was selected with the same probability (Jann,

15 2007). For all the 13 parishes with some industry and for the city of Lucerne a simple

16 random sampling procedure was used (see Figure 1 for an overview of the parishes

17 included). Information on 2,212 marriages was collected on both first and higher-order

18 marriages. As the mating processes might differ for higher-order marriages, data only

19 on first marriages was used for the analyses presented in this article. As a result, the

6 Parishes where the proportion of factory workers exceeded $2 \%$ were included in the stratum of parishes with at least some industry (according to Schnider (1996, p. 48)). 
1 analyses build on data on 1,499 marriages (excluding missing values). ${ }^{7}$ The sampling

2 weights used for the statistical modelling compensate for the over- and under-

3 representation of certain areas due to the stratified design, and ensure that the data set is

4 representative of the whole canton of Lucerne.

\section{$5 \quad 3.2 \quad$ Measuring homogamy}

6 In this article social homogamy is taken to mean that individuals tend to select a spouse

7 of similar social origin. Thus as a first step, the social status of fathers must be

8 measured to estimate the strength of social homogamy for a given area and period. To

9 achieve that the occupational titles included in marriage registers can be coded

10 according to the 'Historical International Classification of Occupations' (HISCO)

11 proposed by van Leeuwen, Maas, and Miles (2002). A scale for occupational

12 stratification is available for this classification-scheme: the 'Historical CAMSIS'

13 (HISCAM) is based on social interactions, and ranks occupations on a continuous status

14 scale (Lambert, Zijdeman, van Leeuwen, Maas, \& Prandy, 2013). ${ }^{8}$ Such a measurement

15 of the status of fathers of brides and grooms means we can use the correlation between

16 the two as a measurement of homogamy by social origin, as it indicates how strongly

17 parents' statuses are associated (graph (a) in Figure 3). Regression models yield an

18 estimate of the effect of the social status of one father on the social status of the other,

19 so that interaction effects can then be used to explain those effects and so to test the

20 hypotheses (graph (b) in Figure 3; for details see the technical discussion at the end of

7380 cases were discounted because either the bride or the groom had been married before, 333 cases were discounted because of missing values for one of the relevant variables.

8 I have used the cross-nationally standardized version 0.1 for this article: HISCAM (2006). 
1 this section).

3 Some of the hypotheses presented in the last section distinguish between homogamy

4 among individuals of lower to middle and high social origin. To include that distinction

5 in the analyses I split the explaining status variable into two linear splines. That means

6 that the relationship between the statuses of the two fathers is not modelled as a single

7 linear function, but rather with two linear functions knotted together. Separate estimates

8 are therefore yielded for the association between the statuses of the fathers of each

9 spouse, one for fathers with low to middle status and one for those of higher status. For

10 this study I set the status of general farmers as the threshold between lower and higher

11 status at (i.e., a HISCAM value of 60.9) so that farmers are at the top of the range of

12 occupations defined here as of "low to medium status". My thinking for that decision

13 was that the occupational structure of the canton of Lucerne was strongly marked by

14 two occupations, namely those of farm workers and of general farmers (compare Figure

154 and its discussion in the next section). While the former were at the low and

16 precarious end of the distribution of fathers' statuses, the latter occupied the highest

17 position in the agrarian sector. Considerably higher positions existed (father's HISCAM

18 values range from 32.5 to 99), but they applied only to a clear minority of the fathers

19 (about $20 \%$ in the city of Lucerne, and only about $6 \%$ in the countryside). From that

20 point of view general farmers therefore stood at the transition point from the lower and

21 middle to higher socials status. ${ }^{9}$ I therefore used two linear splines with a knot at the

9 Figure 4 provides an additional argument for setting the threshold to the HISCAM value of a general farmer (60.9) as the relationship seems to change at this point. 
1 HISCAM value for general farmers to estimate homogamy simultaneously among

2 individuals of lower and middle origin, and of high social origin within the framework

3 of regression models. ${ }^{10}$

\section{$4 \quad 3.3 \quad$ Variables explaining homogamy}

5 The same spline-based approach can be used to model time-trends in homogamy based

6 on the date of a marriage. To test the hypotheses resulting from combining the effects of

7 modernization and marriage restrictions the model should allow the time trend to

8 change at the moment marriage restrictions began to be loosened again. As discussed in

9 the section on the history of Lucerne canton, the marriage restrictions there peaked

10 somewhere between 1856 and 1864 (Bossard-Borner, 2008, pp. 544-548). Because the

11 restrictions were relaxed more rapidly than they were tightened, the turning point

12 appears to be towards the end of that period. Furthermore, the data suggest that the

13 effect on homogamy probably lagged behind the marriage restrictions. I tested three

14 plausible spline definitions and although the differences are small, the solution best

15 fitting the data is one with a knot at the end of the year $1864 .{ }^{11}$ While hypotheses $H 1$

16 predicting decreasing homogamy will be tested by means of linear overall time trends,

10 To enhance the interpretability of the interaction effects the explaining status variable is first centred on the knot before it is transformed to the two splines. When HISCAM is the original status value, the two splines are defined as follows:

$$
\begin{aligned}
& H_{I S C A M}= \begin{cases}H I S C A M-60.9, & \text { if } H I S C A M \leq 60.9 \\
0, & \text { if HISCAM }>60.9\end{cases} \\
& H_{I S C A M}=\left\{\begin{array}{lr}
0, & \text { if } H I S C A M \leq 60.9 \\
H I S C A M-60.9, & \text { if } H I S C A M>60.9
\end{array}\right.
\end{aligned}
$$

${ }^{11}$ Bayesian Information Criteria (BIC) for the basic model are 333190.8 (knot end of 1860), 333160.7 (end of 1862), 333140.9 (end of 1864), and 333142.4 (end of 1866) respectively. 
1 all other time-based hypotheses can be tested by means of two linear splines, one for

2 marriage dates before 1865 and one for marriage dates thereafter. ${ }^{12}$ I modelled those

3 time trends for both the city of Lucerne and the countryside (all other parishes) using

4 three-way interactions between the two splines for the status of fathers, the two splines

5 for dates of marriages, and the indicator for Lucerne city.

6 Two of my variables at parish level are based on external sources. The first

7 stands for the presence of modern transport and indicates that a railway station was

8 available in the corresponding parish at the time of the marriage concerned. The second

9 variable measures the proportion of factory workers in each parish. Schnider (1996,

10 p. 48) reports proportions of factory workers (adjusted for changes in the definition of

11 factories) in the population of each municipality for the years 1856 and 1877, when

12 factory censuses were carried out. Following his description of the economic cycles and

13 waves of factory establishments (Schnider, 1996, pp. 41-69), we may assume that most

14 of the factory jobs recorded in 1856 had been created around 1850, and that many of the

15 additional jobs recorded in 1877 were created around 1865. That then allows a rough

16 estimate of the longitudinal distribution of the proportions of factory workers in

17 parishes. Schnider (1996, p. 48) reports the proportions in five categories: 0\%, 0.1-2\%,

$182.1-5 \%, 5.1-9 \%$, and $9.1-44 \%$. For my analyses, I collapsed the first and the last two

12 As with the explaining status variable, the date of marriage is first centred on the knot before it is transformed to the two splines. When date is the original date of marriage, the two splines are defined as follows:

$$
\begin{aligned}
& \text { date }_{1}= \begin{cases}\text { date }-31 \mathrm{dec} 1864, & \text { if date } \leq 31 \mathrm{dec} 1864 \\
0, & \text { if date }>31 \mathrm{dec} 1864\end{cases} \\
& \text { date }_{2}= \begin{cases}0, & \text { if date } \leq 31 \mathrm{dec} 1864 \\
\text { date }-31 \mathrm{dec} 1864, & \text { if date }>31 \mathrm{dec} 1864\end{cases}
\end{aligned}
$$


1 categories, because tests have shown that this more parsimonious three-fold

2 categorization leads to the same results as the more detailed one. Therefore, my

3 analyses are based on the following categories of proportions of factory workers in the

4 parishes at the time of the marriage: $0-2 \%, 2.1-5 \%$, and $>5 \%$.

\section{$5 \quad 3.4 \quad$ Methodological approach}

6 As pointed out when discussing the correlation between the fathers' statuses as a

7 measure of homogamy, interaction effects in regression models can be used to test

8 hypotheses on factors affecting homogamy. In other words, to test the effects on

9 homogamy of time, city, proximity of railway stations, and the proportion of factory

10 workers, the corresponding variables interact with the two splines representing father's

11 status. However, the directed nature of regression models (one or multiple independent

12 variable(s) explain one dependent variable) does not directly reflect the more or less

13 symmetrical and mutually dependent nature of how spouses select each other. More

14 technically, regression coefficients are sensitive to variance of both the explained and

15 the explaining variable, which can lead to contradictory results. For example, imagine a

16 shrinking variance over time in the status of the groom's father but not of the bride's

17 father, while the correlation between them remains unchanged. In that situation a model

18 explaining groom's father's status by bride's father's status will indicate decreasing

19 homogamy, while the model for the opposite direction of explanation will lead to the

20 opposite conclusion. This is problematic because there is no reason to favour one of the

21 two directions of explanation. A solution to that problem is to estimate both directions

22 of explanation simultaneously, and to constrain the coefficients related to homogamy to 
1 be equal for both directions of explanation. ${ }^{13}$ Unobserved differences between contexts

2 can confound the results, and one way to control for this at least partly is to include

3 random effects on the levels of parishes by estimating multi-level models. ${ }^{14}$ Multi-level

4 models with effects constrained, but simultaneously estimated equations for both

5 directions of explanations can be fitted within the framework of structural equation

13 Constraint across the two directions of explanation are the two splines for father's status and the interaction effects of the covariates with those splines. Not constrained are the constants and the main effects of the covariates.

14 Random slopes for the two status splines allow to control for differences in social homogamy between parishes. Preliminary results showed, however, that the estimated variances of the random slope for the lower status spline was very small. Consequently, the results remain qualitatively the same when removing the random slope. Favouring the more parsimonious of the otherwise equal models, I therefore used multilevel models clustered by parish, with random intercepts and a random slope for the higher (but not for the lower) status splines. The equations read as follows:

$$
\begin{aligned}
& \left|\begin{array}{l}
\operatorname{HISCAM}_{b f_{i p}}=\beta_{i p}^{\text {low }} \cdot \operatorname{HISCAM}_{g f_{i p}}^{\text {low }}+\beta_{i p}^{\text {high }} \cdot \operatorname{HISCAM}_{g f_{i p}}^{\text {high }}+\gamma^{b} \cdot X_{i p}+\mu_{p}^{b}+\varepsilon_{i}^{b} \\
\operatorname{HISCAM}_{g f_{i p}}=\beta_{i p}^{\text {low }} \cdot \operatorname{HISCAM}_{b f_{i p}}^{\text {low }}+\beta_{i p}^{\text {high }} \cdot \operatorname{HISCAM}_{b f_{i p}}^{\text {high }}+\gamma^{g} \cdot X_{i p}+\mu_{p}^{g}+\varepsilon_{i}^{g}
\end{array}\right| \\
& \beta_{p}^{\text {low }}=\alpha^{\text {low }}+\delta^{\text {low }} \cdot X_{i p} \quad \beta_{p}^{\text {high }}=\alpha^{\text {high }}+\delta^{\text {high }} \cdot X_{i p}+\tau_{p}
\end{aligned}
$$

where $H_{I S C A M} f_{i p}$ and HISCAM $g f_{i p}$ is the HISCAM of the fathers of bride and groom, $X_{i p}$ is a set of covariates (varying either on individual- or parish-level (subscript $i$, and $p$, respectively)), $\beta_{i p}^{\text {low }}$ and $\beta_{i p}^{\text {high }}$ are the homogamy parameters for low and high status homogamy, $\alpha$ and $\beta$ are parameters explaining homogamy (constraint to be equal for both equations), $\tau_{p}$ is a random slope, $\gamma$ are the equation-specific parameters of the main effects, and $\mu_{p}$ an equation-specific random intercept. 
1 models. $^{15}$

2 The results for homogamy presented in the next section are based on four such

3 models. The first model uses linear time trends to estimate homogamy over time for

4 rural areas and Lucerne city. The second replaces the overall time trend by two linear

5 splines, in order to test changing trends. The third and fourth models additionally

6 include the variables for a nearby railway station, or dummy variables for parishes with

7 respectively a factory worker proportion of $2.1-5 \%$ and more than $5 \% .{ }^{16}$ For these

8 models, the observations from the city of Lucerne have been excluded, as there is not

9 enough contextual variation to estimate the effect of the two variables. To enhance the

10 readability of the results only post-estimation results (such as average marginal effects

11 or linear combinations of the coefficients) and graphical representations of the

12 coefficients are reported in the main body of the article (but compare the full regression

13 tables for all models in the appendix).

\section{Results}

15 As outlined in the last section, this article understands social homogamy as the

16 correlation between the status of a bride's father and that of a groom's father. It is an

17 inherently bivariate concept which cannot be measured on the individual level nor

18 reported in tables with descriptive statistics. All the same, Table 1 gives a first overview

15 I should like to thank publicly here one of the anonymous reviewers for the suggestion to use structural equation models to combine the advantages of the constraint approach with those of multi-level models. Models estimated using Stata 15 (StataCorp, 2017).

16 To avoid biases caused by collider variables I used separate models to estimate the effects of availability of a nearby railway station and of industrialization (Elwert \& Winship, 2014). 
1 of the measures behind homogamy: the status of the groom's and bride's fathers

2 measured on the HISCAM scale. Overall, the distribution of the two are similar. They

3 range from 32.5 (HISCAM value for not closer defined workers) to 99 (HISCAM value

4 assigned to occupations such as medical doctors, lawyers, or professors), have a mean

5 of between 51 and 52 ('cartwright' is a frequent occupation in this range) and a standard

6 deviation of about 12. The fathers of a couple who were married in the city had a status

7 on average about half a standard deviation higher than the fathers of those who married

8 in the countryside. While the average of the bride's father's status is slightly higher than

9 that of the groom's father, the mean difference and the individual difference are

10 marginally significant at most (unpaired: $t(2996)=1.27, p=.20$ and paired:

$11 t(1498)=1.77, p=.08$ respectively).

12

---Table 1 about here---

16 Figure 4 gives a first impression of the association between the statuses of the two

17 fathers. The scatterplots, both for the countryside and for the city, are characterized by a 18 square in the lower left corner, formed by farm labourers (HISCAM: 37.1) and general

19 farmers (HISCAM: 60.9). The graph shows too that a daughter or son of a farm labourer

20 rarely married the son or daughter of a man whose occupational status was higher than

21 that of a general farmer. Although the social stratification of the fathers of those married

22 in the city was also marked by farming occupations, their statuses were clearly more

23 evenly distributed around the mean. In the countryside, by contrast, the picture was

24 dominated by occupations with rather low statuses. 
2 statuses were locally associated. Three observations from those smoothers are

3 noteworthy. First, the relationship in the countryside was steeper overall than that in the

4 city. Simple correlations confirm that observation, as it was substantially tighter outside

$5 \quad(r=.54)$ than inside the city of Lucerne $(r=.31)$. Second, for rural Lucerne, the lpoly

6 line bends just above the status of general farmers (HISCAM 60.9), while the

7 relationship is otherwise rather linear, both inside and outside the city. Third, whereas

8 the two directions of explanation generally agree very well, that is less true for higher

9 status in the countryside.

10 Two aspects concerning the other variables deserve to be highlighted. First, the 11 means of year of marriage lie after the middle of the observed period (1834-75),

12 especially in the city. That stems from an increase in marriages towards the end of the 13 period. Second, although the factory industry particularly flourished around the city of

14 Lucerne, the proportion of factory workers in the city itself never surpassed the

15 threshold of $2 \%$.

\section{$16 \quad 4.1$ City versus countryside}

17 Comparing homogamy in rural Lucerne and the city of Lucerne, the results presented in

18 Figure 5 show distinct results for homogamy between individuals of lower and higher

19 social origin. In rural Lucerne, a high level of homogamy can be found for marriages of

20 couples of low and middle status origin. On average, one partner's father's status was

21.63 points higher on the HISCAM scale if the other partner's father had a status that was

22 one point higher. At the same time, homogamy among high origin individuals was very

23 low in the countryside, and cannot be said to be significantly different from zero - also

24 because of the low number of observations. In the city of Lucerne, the situation was 
1 different. On the low to middle origin side, the association was estimated at .25 - about

2.38 lower than in the countryside $(p<.001)$. In contrast to the countryside, homogamy

3 among high origin individuals in the city seems to have been higher than among those

4 of low to middle origin, although the difference between low and high origin

5 homogamy is not statistically significant $(p=.177)$. However, homogamy among those

6 of higher social origin was clearly stronger for couples married in the city than for those

7 married in other parishes. Because of the low number of cases, that difference is

8 imprecisely estimated and only marginally significant $(p=.052)$.

9

--- Figure 5 about here---

10 In sum, the model yields mixed results for the contrast between the city and the

11 countryside. For individuals of lower or middle social origin (the vast majority of the

12 population), social homogamy according to parental status was considerably lower in

13 the city than in rural Lucerne. That is in line with the prediction of the modernization

14 thesis (hypothesis $H 2$ ) although that conclusion is not valid for the elites. Homogamy

15 among individuals of high social origin was notable in the city of Lucerne but very low

16 and perhaps even non-existent in rural areas.

\section{$17 \quad 4.2 \quad$ Time trends}

18 Turning to time trends in social homogamy, the distinction between homogamy among

19 couples from lower and middle origin on the one hand, and those from high origin on

20 the other, continued to be important - especially in the rural part of the canton. I

21 estimated two models (appendix, Table A1) to test hypotheses on general time trends

$22(H 1)$, changing trends due to changing marriage restrictions $(H 3)$, and on the

23 combination of the two $(H 4)$. While the first includes one linear time trend for the

24 whole period, the second uses two linear splines. 
1 Figure 6, based on this latter model, displays the estimated association between the two

2 fathers' statuses by date of marriage separately for lower and higher origin individuals,

3 and for the city and parishes outside the city of Lucerne. It gives a straightforward

4 overview of the different time trends. For a more precise interpretation of the strength

5 and statistical significance of the time trends, Table 2 reports the estimated yearly

6 changes, separately for the overall trend and for the two splines.

7

8

9

10

11

12

---Table 2 about here---

Figure 6 does not reveal a pronounced overall trend. While in rural Lucerne homogamy among higher status individuals was declining over the whole period, the very wide confidence intervals suggest imprecisely estimated trends. Table 2 confirms that impression, for with one exception the overall trends are neither strong nor statistically significant. The exception concerns homogamy among higher status individuals married in the city of Lucerne, which slowly but significantly strengthened over time.

If we look at the periods before and after 1865 separately, we see that the trends were more pronounced. With the exception of higher status homogamy in rural areas all trends followed the same pattern as homogamy increased from 1834-64 but decreased after then (all trends are statistically significant except the decrease of homogamy among individuals from lower and middle origin in rural Lucerne $(p=.119))$.

From those results we can infer that the changing severity of the marriage restrictions was the main driver of the trends in homogamy (hypothesis H3). In other words, homogamy's development paralleled the changing nature of the marriage restrictions, as described in the literature (Bossard-Borner, 1998, 2008). In Lucerne city 
1 this was true for individuals from all social strata, while in rural Lucerne no clear trends

2 have been found for those from higher social origins. That is only partly in line with the

3 rationale behind the hypotheses for the combined effect of modernization and marriage

4 restrictions (H4), assuming only the lower strata were affected by the changing marriage

5 restrictions.

6 No evidence was found to support the hypothesis that modernization caused

7 homogamy to decrease over time $(H 1)$. It is possible that such a trend did exist but was

8 completely masked by other processes, such as the changing marriage restrictions.

9 However, the fact that the only significant overall trend points in the opposite direction

10 suggests that the modernization thesis is missing an important aspect, at least for this

11 early phase of modernization.

\section{$12 \quad 4.3 \quad$ Direct measures}

13 While the time trends do not directly reflect effects on homogamy of modernization, the

14 story told by the direct measures of industrialization and modernization is more

15 nuanced. While the results presented in Figure 7 do not suggest that a rail connection

16 affected homogamy, the proportion of factory workers in a parish did matter.

18 Regarding homogamy among individuals of low and middle origin, the results are in

19 line with hypothesis H6. In that part of the population homogamy decreased with the

20 proportion of factory workers in the parish. It was moderately and marginally

21 significantly lower in parishes where the proportion of factory workers surpassed $2 \%$,

22 and clearly and highly significantly lower where it exceeded 5\%. In respect to

23 homogamy among high-origin individuals, the results remain unclear. While the

24 coefficients are strongly negative, the very large confidence intervals do not permit us 
1 to come to any conclusion.

\section{Conclusion and discussion}

3 In addition to new data, three original features of this study have allowed new insights

4 into the effects of social origin on the spouse selection process during the course of

5 modernization, both in general and specifically with respect to the canton of Lucerne.

6 First, regarding the marriage restrictions I have explicitly considered a phenomenon

7 which interferes with the effects on social homogamy of modernization and

8 industrialization. Next, I have presented theoretical arguments and empirical evidence

9 for a fruitful separation of the analysis of homogamy by social strata. Finally, I have

10 proposed analysing homogamy using multilevel models with constraint simultaneous

11 equations for both directions of explanation. This has provided a way of making

12 available the advantages of multilevel models for the analysis of homogamy by social

13 origin, while respecting its symmetrical and mutually dependent nature.

14 The results yielded by this approach lead to three conclusions. An interesting

15 first finding is that the homogamy of couples of lower and middle origin was far

16 stronger in rural areas than in the city, while the opposite was true for couples of high

17 social origin. In rural areas the strong homogamy among lower origin individuals was

18 probably the result of the strong homogamy within the farming community (Bull, 2005;

19 Dribe \& Lundh, 2009) whereas the very weak high status homogamy may be attributed

20 to the fact that in rural areas it was difficult to find a partner of similarly high origin

21 (van Leeuwen \& Maas, 2005, p. 10). Differences in social homogamy between the rural

22 part of the canton and the city of Lucerne were probably caused by two things. First,

23 because of long-standing specificities in patterns of family formation in the cities

24 (Lynch, 1991) and second because of strong migration to the city that itself affected the 
1 processes behind family formation (Moreels \& Matthijs, 2010; Schumacher, Matthijs, \&

2 Moreels, 2013). Future research focusing on the difference between the city and the

3 countryside should therefore consider both bride's and groom's migration background

4 in order to disentangle the two effects.

A first conclusion from the tests of the derived hypotheses is that they are

6 generally supported by the data, but mainly in respect to homogamy among individuals

7 of lower and middle social origin. For that part of the population, the time trends found

8 in homogamy were in line with presumptions about the effect of marriage restrictions.

9 In other words, homogamy in the canton of Lucerne was strong around 1865 when the

10 marriage restrictions peaked, but lower before and after that peak. That is in line with

11 hypotheses $H 3$ and $H 4$ and fits neatly into the picture of the inequality-preserving

12 effects of marriage restrictions drawn by Mantl (1999). In that part of the population the

13 modernization thesis, too, receives support, at least partially. On the one hand the higher

14 homogamy found in the countryside than in the city (H2), and the existing negative

15 relationship between the proportion of factory workers and homogamy $(H 6)$, both

16 support the modernization thesis. On the other hand, a general modernization trend in

17 homogamy $(H 1)$ was either too weak to offset the effect of the increasing marriage

18 restrictions in the period before 1865 or did not exist at all. Furthermore, the presumed

19 negative relationship between an existing connection to the railway system and

20 homogamy (H5) could not be confirmed by the data from Lucerne. As described in the

21 section on the canton of Lucerne, the canton was clearly modernizing during the $19^{\text {th }}$

22 century - for example in agriculture and education - but industrialization was limited to

23 a few areas. We may therefore interpret the results in the sense that industrialization

24 alone, and no other aspects of modernization, affected homogamy in the canton of

25 Lucerne. That conclusion is broadly in line with previous research on homogamy during 
1 early modernization, as most studies found no clear time trends (Bull, 2005; Dribe

2 \& Lundh, 2009; Maas \& van Leeuwen, 2005; van Leeuwen \& Maas, 2002) although

3 they did find effects of more directly measured industrialization (Lippényi, van

4 Leeuwen, Maas, \& Öri, 2017; Maas et al., 2011; Zijdeman \& Maas, 2010). Decreasing

5 homogamy by social origin with industrialization suggests that industrialization did

6 indeed change something in the process of family formation. The result is an indication

7 that the influence of parents on family formation diminished during the course of

8 industrialization. In Lucerne, evidence for that can be found only by analysing the effect

9 of directly measured industrialization, as suggested by Puschmann and Solli (2014). The

10 fact that industrialization effects have been found in Lucerne is remarkable insofar as

11 industrialization remained relatively weak even in the areas of the canton that were

12 further industrialized.

13 While the results for homogamy among individuals of lower and middle origin

14 are essentially in line both with my hypotheses and with previous research, that is not

15 true for homogamy in couples of higher social origin. Although the small number of

16 cases mean that the estimates are imprecise, nevertheless two results clearly contradict

17 the hypotheses derived from the modernization thesis. In that higher stratum homogamy

18 was much stronger in the city than in rural Lucerne, and in the city the overall trend

19 towards homogamy was positive, not negative as claimed by the modernization thesis.

20 Building on sector dualism discussed by Kuznets (1955), the idea of generalized

21 dualism fits these observations, for it assumes that modernization processes such as

22 industrialization or educational expansion, first increase and only later decreases

23 inequality (Knigge et al., 2014; Nielsen, 1994). If increasing concentration of income

24 and wealth was relevant to homogamy it is probable that it affected mainly individuals

25 of high social origin. Consequently, for those couples increasing inequality might have 
1 counteracted the otherwise decreasing importance of social origin and led to the

2 observed increase of homogamy by social origin.

3

4

In the end this study is limited by the data, especially with respect to the population from higher origin brackets. Although the newly collected dataset used for this article includes 1,499 usable observations, it is still relatively small, especially compared against other historical datasets that have grown over time, like the databases from Sweden (Landsarkivet i Lund, 2016; Umeå University, 2016) or the Netherlands (Centraal Bureau voor Genealogie, 2016). That relatively small size naturally limits the data's statistical power, especially if a number of sub-groups are analysed. Furthermore, additional high quality indicators for modernization on the level of the individual parishes would clearly extend the scope of those aspects of modernization which could be analysed.

3 Despite those limitations the new data allows us to study aspects of social stratification in an agrarian area which was partly industrializing during the $19^{\text {th }}$ century. It also allows research on social homogamy to be expanded into a hitherto unstudied context, but most importantly this data has led to the generation of new insights that are worth further investigation. Three key findings raise questions for future research. First, the findings suggest that the relevant mechanisms can differ by social strata. Future researchers might want to respect heterogeneous effects by social strata in order to avoid glossing over existing differences. The second finding reminds us that historical processes are rarely unidimensional and monotonous. In Lucerne, pauperism was attributed to industrialization outside the canton, and the authorities reacted by tightening marriage restrictions. The time trends found in homogamy support the assumption that Lucerne's tightening of its marriage restrictions amplified the importance of social origin in respect to spouse selection, counteracting the effect of 
1 modernization. Future research might add to this finding by both explicitly considering

2 and directly measuring political or social reactions to modernization when analysing

3 modernization processes. All the more so in fact, since the third finding confirms the

4 conclusion of previous studies that modernization effects should be tested as directly as

5 possible (Maas et al., 2011; Puschmann \& Solli, 2014; Zijdeman \& Maas, 2010).

6 Although the time trends in the canton of Lucerne did not reflect any effects of

7 modernization, direct measurements show that industrialization had an effect on

8 homogamy by social origin. 


\section{Archival sources}

2 Staatsarchiv Luzern (=StALU; State Archives of Lucerne):

3

4

5

\section{References}

7 Balthasar, A. (1988). Luzern: vom Städtchen zur Stadt: Die langfristige

8 Bevölkerungsentwicklung 1700-1930 unter Anwendung der "Generalized Inverse

9 Projection" [Lucerne: From a small town to a city. Demographic development in the

10 long term (1700-1930), with an application of the "generalized inverse projection"].

11 Schweizerische Zeitschrift für Geschichte, 38, 1-29. https://doi.org/10.5169/seals-

1280990

13 Becker, G. S. (1973). A Theory of Marriage: Part I. Journal of Political Economy, $14 \quad 81(4), 813-846$.

15

Blau, P. M., \& Duncan, O. D. (1967). The American Occupational Structure. New York: Wiley.

Blossfeld, H.-P. (2009). Educational Assortative Marriage in Comparative Perspective. Annual Review of Sociology, 35, 513-530.

Blossfeld, H.-P., \& Timm, A. (2003). Educational Systems as Marriage Markets in Modern Societies: A Conceptual Framework. In H.-P. Blossfeld \& A. Timm (Eds.), European studies of population: vol. 12. Who Marries Whom? Educational Systems as Marriage Markets in Modern Societies (pp. 1-18). Dordrecht: Kluwer.

Boesch, G., \& Kottmann, A. (1974). 400 Jahre Höhere Lehranstalt Luzern, 1574-1974 [400 years of institutions of higher education in Lucerne, 1574-1974]. Luzern: Verlag Kantonsschule Luzern. 
1 Bossard-Borner, H. (1998). Im Bann der Revolution: Der Kanton Luzern 1798-1831/50

2 [Under the spell of the revolution. The canton of Lucerne 1798-1831/50]. Luzerner

3 historische Veröffentlichungen: Vol. 34. Luzern, Stuttgart: Rex.

4 Bossard-Borner, H. (2008). Im Spannungsfeld von Politik und Religion: Der Kanton

$5 \quad$ Luzern 1831 bis 1875 [In the conflicting fields of politics and religion. The canton of

6 Lucerne, 1831-1875]. Luzerner historische Veröffentlichungen: Vol. 42. Basel:

$7 \quad$ Schwabe.

8 Bossard-Borner, H. (2010). Luzern (Kanton): Kap. 4.1 Politische Geschichte und

9 Verfassungsgeschichte [Lucerne (canton). Chap. 4.1 Political and constitutional

10 history]. In $H L S$. Retrieved from http://www.hls-dhs-dss.ch/textes/d/D7382.php

11 Boudon, R. (1974). Education, opportunity, and social inequality: Changing prospects

12 in western society. New York: Wiley.

13 Breen, R. (Ed.). (2004). Social mobility in Europe. Oxford: Oxford University Press.

14 Bull, H. H. (2005). Deciding Whom to Marry in a Rural Two-Class Society: Social

15 Homogamy and Constraints in the Marriage Market in Rendalen, Norway, 1750-

16 1900. International Review of Social History, 50(S13), 43.

17 https://doi.org/10.1017/S0020859005002063

18 Centraal Bureau voor Genealogie. (2016). WieWasWie. Retrieved from

19 https://www.wiewaswie.nl/en/home/

20 Dribe, M., \& Lundh, C. (2009). Partner choice and intergenerational occupational

21 mobility: the case of nineteenth-century rural Sweden. Continuity and Change, 24(Special Issue 03), 487-512. https://doi.org/10.1017/S0268416009990178 
1 Dubler, A.-M. (1983). Geschichte der Luzerner Wirtschaft: Volk, Staat und Wirtschaft

2 im Wandel der Jahrhunderte [History of the economy in Lucerne. People, state and

3 economy over the centuries]. Luzern, Stuttgart: Rex.

4 Dufour, G.-H. (1855). Topographische Karte der Schweiz [Topographic map of

5 Switzerland]. Retrieved from https://s.geo.admin.ch/6ad0a6d0a5

6 Edwards, J. N. (1969). Familial Behavior as Social Exchange. Journal of Marriage and

$7 \quad$ Family, 31(3), 518-526. https://doi.org/10.2307/349775

8 Ehmer, J. (2011). Quantifying mobility in early modern Europe: the challenge of

9 concepts and data. Journal of Global History, 6(02), 327-338.

10 https://doi.org/10.1017/S1740022811000301

11 Elwert, F., \& Winship, C. (2014). Endogenous Selection Bias: The Problem of

12 Conditioning on a Collider Variable. Annual Review of Sociology, 40(1), 31-53.

13 https://doi.org/10.1146/annurev-soc-071913-043455

14 Erikson, R., \& Goldthorpe, J. H. (1992). The Constant Flux: A Study of Class Mobility

15 in Industrial Societies. Oxford [England], New York: Clarendon Press; Oxford

16 University Press.

17 Goode, W. J. (1964). The family. Foundations of modern sociology series. Englewood 18 Cliffs (N.J.): Prentice-Hall.

19 Gössi, A., \& Huber, M. (2001). Die Pfarrbücher und Zivilstandsregister im

20 Staatsarchiv Luzern: Findbuch zu den Abschriften, Filmen und Originalbänden [The

21 Church Books and Civil Registers in the State Archives of Lucerne. Finding Aid to the Transcripts, Films, and Original Volumes]. Luzerner historische

23 Veröffentlichungen. Archivinventare: Vol. 6. Basel: Schwabe. 
1 Hajnal, J. (1953). The Marriage Boom. Population Index, 19(2), 80-101.

2 https://doi.org/10.2307/2730761

3 Hajnal, J. (1965). European Marriage Patterns in Perspective. In D. V. Glass \& D. E. C.

$4 \quad$ Eversley (Eds.), Population in history: Essays in historical demography (pp. 101-

5 143). London: E. Arnold.

6 Head-König, A.-L. (1993). Forced marriages and forbidden marriages in Switzerland:

7 State control of the formation of marriage in catholic and protestant cantons in the

8 eighteenth and nineteenth centuries. Continuity and Change, 8(03), 441-465.

9 https://doi.org/10.1017/S0268416000002186

10 Head-König, A.-L. (1999). Les apports d'une immigration féminine traditionnelle à la

11 croissance des villes de la Suisse: Le personnel de maison féminin (XVIIIe-début du

$12 \mathrm{XXe}$ siècle) [The contribution of the traditional female migration to the growth of

13 Swiss cities. The female housekeeping service workers (18th to early 20 th century)].

14 Schweizerische Zeitschrift für Geschichte, 49, 47-63. https://doi.org/10.5169/seals-

$15 \quad 81243$

16 HISCAM. (2006). HIS-CAM scale version 0.1. Retrieved from

17 http://www.camsis.stir.ac.uk/hiscam/

18 Hout, M., \& DiPrete, T. A. (2006). What We Have Learned: RC28's Contributions to

19 Knowledge About Social Stratification. Research in Social Stratification and

20 Mobility, 24(1), 1-20. https://doi.org/10.1016/j.rssm.2005.10.001

21 Jann, B. (2007). Überlegungen zum Berner Stichprobenplan [Reflections on the Bernese

22 Sampling Plan]. Schweizerische Zeitschrift für Soziologie, Vol. 33(2), 307-325. 
1 Janssens, A. (1986). Industrialization without Family Change? The Extended Family

2 and the Life Cycle in a Dutch Industrial Town, 1880-1920. Journal of Family

3 History, 11(1), 25-42. https://doi.org/10.1177/036319908601100102

4 Kalmijn, M. (1991a). Shifting Boundaries: Trends in Religious and Educational

$5 \quad$ Homogamy. American Sociological Review, 56(6), 786-800.

6 https://doi.org/10.2307/2096256

7 Kalmijn, M. (1991b). Status Homogamy in the United States. American Journal of $8 \quad$ Sociology, 97(2), 496-523.

9 Kalmijn, M. (1998). Intermarriage and Homogamy: Causes, Patterns, Trends. Annual $10 \quad$ Review of Sociology, 24, 395-421.

11 Kalmijn, M., \& Flap, H. (2001). Assortative Meeting and Mating: Unintended

12 Consequences of Organized Settings for Partner Choices. Social Forces, 79(4),

13 1289-1312. https://doi.org/10.1353/sof.2001.0044

14 Kanton Luzern. (1831-1840). Sammlung der Gesetze und Regierungs-Verordnungen

15 für den Kanton Luzern [Collection of laws and governmental ordinances for the 16 canton of Lucerne]. Luzern: X. Meyer.

17 Kerr, C., Dunlop, J. T., Harbison, F. H., \& Myers, C. A. (1960). Industrialism and

18 Industrial Man: The Problems of Labor and Management in Economic Growth.

19 London: Heinemann.

20 Knigge, A., Maas, I., van Leeuwen, M. H. D., \& Mandemakers, K. (2014). Status

21 Attainment of Siblings during Modernization. American Sociological Review, 79(3), 549-574. https://doi.org/10.1177/0003122414529586 
1 Kok, J., \& Leinarte, D. (2015). Cohabitation in Europe: a revenge of history? The

$2 \quad$ History of the Family, 20(4), 489-514.

3 https://doi.org/10.1080/1081602X.2015.1067240

4 Kuznets, S. (1955). Economic Growth and Income Inequality. The American Economic

$5 \quad$ Review, 45(1), 1-28. Retrieved from http://www.jstor.org/stable/1811581

6 Lambert, P. S., Zijdeman, R. L., van Leeuwen, M. H. D., Maas, I., \& Prandy, K. (2013).

7 The Construction of HISCAM: A Stratification Scale Based on Social Interactions

8 for Historical Comparative Research. Historical Methods: A Journal of Quantitative

$9 \quad$ and Interdisciplinary History, 46(2), 77-89.

10 https://doi.org/10.1080/01615440.2012.715569

11 Landsarkivet i Lund. (2016). DDSS - Demografisk Databas Södra Sverige. Retrieved

12 from http://ddss.nu/english/default.aspx

13 Laslett, P. (Ed.). (1974). Household and family in past time: Comparative studies in the

14 size and structure of the domestic group over the last three centuries in England,

15 France, Serbia, Japan and colonial North America, with further materials from

16 Western Europe (2nd ed.). London: Cambridge University Press.

17 Le Play, F. (1877-79). Les ouvriers européens [European laborers]. Tours: Alfred

18 Mame.

19 Lippényi, Z., Maas, I., \& van Leeuwen, M. H. D. (2015). Modernization and Social

20 Fluidity in Hungary, 1870-1950. European Sociological Review, 31(1), 103-114.

21 https://doi.org/10.1093/esr/jcu085

22 Lippényi, Z., van Leeuwen, M. H. D., Maas, I., \& Öri, P. (2017). Social status

23 homogamy in a religiously diverse society. Modernization, religious diversity, and 
1 status homogamy in Hungary between 1870-1950. The History of the Family,

2 advance online publication. https://doi.org/10.1080/1081602X.2017.1319399

3 Lipset, S. M., \& Zetterberg, H. L. (1959). Social Mobility in Industrial Societies. In S.

$4 \quad$ M. Lipset \& R. Bendix (Eds.), Social mobility in industrial society (pp. 11-75).

5 London: Heinemann.

6 Lischer, M. (2016). Luzern (Gemeinde) [Lucerne (municipality)]. In HLS. Retrieved

7 from http://www.hls-dhs-dss.ch/textes/d/D7382.php

8 Lynch, K. A. (1991). The European Marriage Pattern in the Cities: Variations on a

9 Theme by Hajnal. Journal of Family History, 16(1), 79-96.

10 https://doi.org/10.1177/036319909101600106

11 Maas, I., \& van Leeuwen, M. H. D. (2005). Total and Relative Endogamy by Social

12 Origin: A First International Comparison of Changes in Marriage Choices during the

13 Nineteenth Century. International Review of Social History, 50(S13), 275-295.

14 https://doi.org/10.1017/S0020859005002142

15 Maas, I., \& van Leeuwen, M. H. D. (2016). Toward Open Societies? Trends in Male

16 Intergenerational Class Mobility in European Countries during Industrialization.

17 American Journal of Sociology, 122(3), 838-885. https://doi.org/10.1086/689815

18 Maas, I., van Leeuwen, M. H. D., Pélissier, J.-P., \& Rébaudo, D. (2011). Economic

19 development and parental status homogamy: A study of 19th century France.

20 Marriage patterns, household formation and economic development, 16(4), 371-386.

21 https://doi.org/10.1016/j.hisfam.2011.07.006

22 Mantl, E. (1999). Legal restrictions on marriage. The History of the Family, 4(2), 185-

23 207. https://doi.org/10.1016/S1081-602X(99)00011-1 
1 Matz, K.-J. (1980). Pauperismus und Bevölkerung: Die gesetzlichen

2 Ehebeschränkungen in den süddeutschen Staaten während des 19. Jahrhunderts

3 [Pauperism and population. The legal marriage restrictions in the south-German

$4 \quad$ states during the 19th century]. Industrielle Welt: Vol. 31. Stuttgart: Klett-Cotta.

5 Mergel, T. (2012). Modernization. In European History Online (EGO). Retrieved from

6 http://www.ieg-ego.eu/mergelt-2011-en

7 Merton, R. K. (1941). Intermarriage and the social structure: Fact and theory.

8 Psychiatry, 4(3), 361-374.

9 Milanović, B. (2016). Global inequality: A new approach for the age of globalization.

10 Cambridge, London: The Belknap Press of Harvard University Press.

11 Moreels, S., \& Matthijs, K. (2010). Marrying in the City in Times of Rapid

12 Urbanization. Journal of Family History, 36(1), 72-92.

13 https://doi.org/10.1177/0363199010390615

14 Nielsen, F. (1994). Income Inequality and Industrial Development: Dualism Revisited. 15 American Sociological Review, 59(5), 654-677. https://doi.org/10.2307/2096442

16 Ortmayr, N. (1995). Late Marriage: Causes and Consequences of the Austrian Alpine

17 Marriage Pattern. In R. L. Rudolph (Ed.), Liverpool studies in European population:

18 Vol. 4. The European peasant family and society: Historical studies (pp. 49-63).

19 Liverpool: Liverpool University Press.

20 Parsons, T. (1960). Structure and process in modern societies. New York: Free Press.

21 Pfenniger, P. (1998). Zweihundert Jahre Luzerner Volksschule, 1798-1998 [Two-

22 hundred years of public schooling in Lucerne, 1798-1998]. Luzern: Historisches

23 Museum. 
1 Piketty, T. (2013). Le capital au XXIe siècle [Capital in the twenty-first century]. Paris:

2 Éditions du Seuil.

3 Puschmann, P., \& Solli, A. (2014). Household and family during urbanization and 4 industrialization: Efforts to shed new light on an old debate. The History of the $5 \quad$ Family, 19(1), 1-12. https://doi.org/10.1080/1081602X.2013.871570

6 Schnider, P. (1996). Fabrikindustrie zwischen Landwirtschaft und Tourismus:

$7 \quad$ Industrialisierung der Agglomeration Luzern zwischen 1850 und 1930 [Factory

8 industry between agriculture and tourism. Industrialization of the surroundings of

9 Lucerne between 1850 and 1930]. Luzerner historische Veröffentlichungen: Bd. 31.

10 Luzern [etc.]: Rex.

11 Schumacher, R., \& Lorenzetti, L. (2005). Social Stratification and Occupational

12 Homogamy in Industrial Switzerland, Winterthur 1909/10-1928. International

13 Review of Social History, 50(S13), 65. https://doi.org/10.1017/S0020859005002075

14 Schumacher, R., Matthijs, K., \& Moreels, S. (2013). Migration and reproduction in an 15 urbanizing context. Family life courses in $19^{\text {th }}$ century Antwerp and Geneva. Revue 16 Quetelet, 1(1), 19-40. https://doi.org/10.14428/rqj2013.01.01.03

17 Schwartz, C. R. (2013). Trends and Variation in Assortative Mating: Causes and

18 Consequences. Annual Review of Sociology, 39(1), 451-470.

19 https://doi.org/10.1146/annurev-soc-071312-145544

20 Simpson, M. (1990). Political Rights and Income Inequality: A Cross-National Test. 21 American Sociological Review, 55(5), 682-693. https://doi.org/10.2307/2095864

22 StataCorp. (2017). Stata Statistical Software: Release 15. College Station, TX:

23 StataCorp LLC. 
1 Tipps, D. C. (1973). Modernization Theory and the Comparative Study of National

2 Societies: A Critical Perspective. Comparative Studies in Society and History, 15(2),

3 199-226. https://doi.org/10.1017/S0010417500007039

4 Treiman, D. J. (1970). Industrialization and Social Stratification. Sociological Inquiry, $5 \quad$ 40(2), 207-234. https://doi.org/10.1111/j.1475-682X.1970.tb01009.x

6 Umeå University. (2016). Demographic Data Base. Retrieved from

7 www.cedar.umu.se/english/ddb/

8 van Leeuwen, M. H. D., \& Maas, I. (2002). Partner Choice and Homogamy in the

9 Nineteenth Century: Was There a Sexual Revolution in Europe? Journal of Social $10 \quad$ History, 36(1), 101-123.

11 van Leeuwen, M. H. D., \& Maas, I. (2005). Endogamy and Social Class in History: An 12 Overview. International Review of Social History, 50(S13), 1-23.

13 https://doi.org/10.1017/S002085900500204X

14 van Leeuwen, M. H. D., Maas, I., \& Miles, A. (2002). HISCO: Historical international 15 standard classification of occupations: Leuven University Press.

16 van Leeuwen, M. H. D., Maas, I., Rébaudo, D., \& Pélissier, J.-P. (2016). Social

17 mobility in France 1720-1986: effects of wars, revolution and economic change:

18 Effects of Wars, Revolution and Economic Change. Journal of Social History, 49(3),

19 585. https://doi.org/10.1093/jsh/shv054

20 Wägli, H. G., \& Jacobi, S. (2010). Schienennetz Schweiz: Strecken, Brücken, Tunnels.

21 Ein technisch-historischer Atlas [Swiss railway network. Tracks, bridges, tunnels. A technical and historical atlas] (3rd ed.). Zürich: AS Verlag \& Buchkonzept.

23 Widmer, E. (1993). De coeur et de raison: Le choix du conjoint à Genève au XIX ${ }^{e}$

24 siècle. Genève: Société d'Histoire et d'Archéologie de Genève; Diff. Libr. Droz. 
1 Zijdeman, R. L. (2009). Like my father before me: Intergenerational occupational status

2 transfer during industrialization (Zeeland, 1811-1915). Continuity and Change,

3 24(03), 455. https://doi.org/10.1017/S0268416009990166

4 Zijdeman, R. L., \& Maas, I. (2010). Assortative mating by occupational status during

5 early industrialization. Research in Social Stratification and Mobility, 28(4), 395-

6 415. https://doi.org/10.1016/j.rssm.2010.06.004

7

8 
16 Appendix

2

--- Table A1 about here---

3

4

--- Table A2 about here---

5 


\section{$\begin{array}{lll}1 & 7 & \text { Tables }\end{array}$}

2 Table 1. Descriptive statistics of variables used

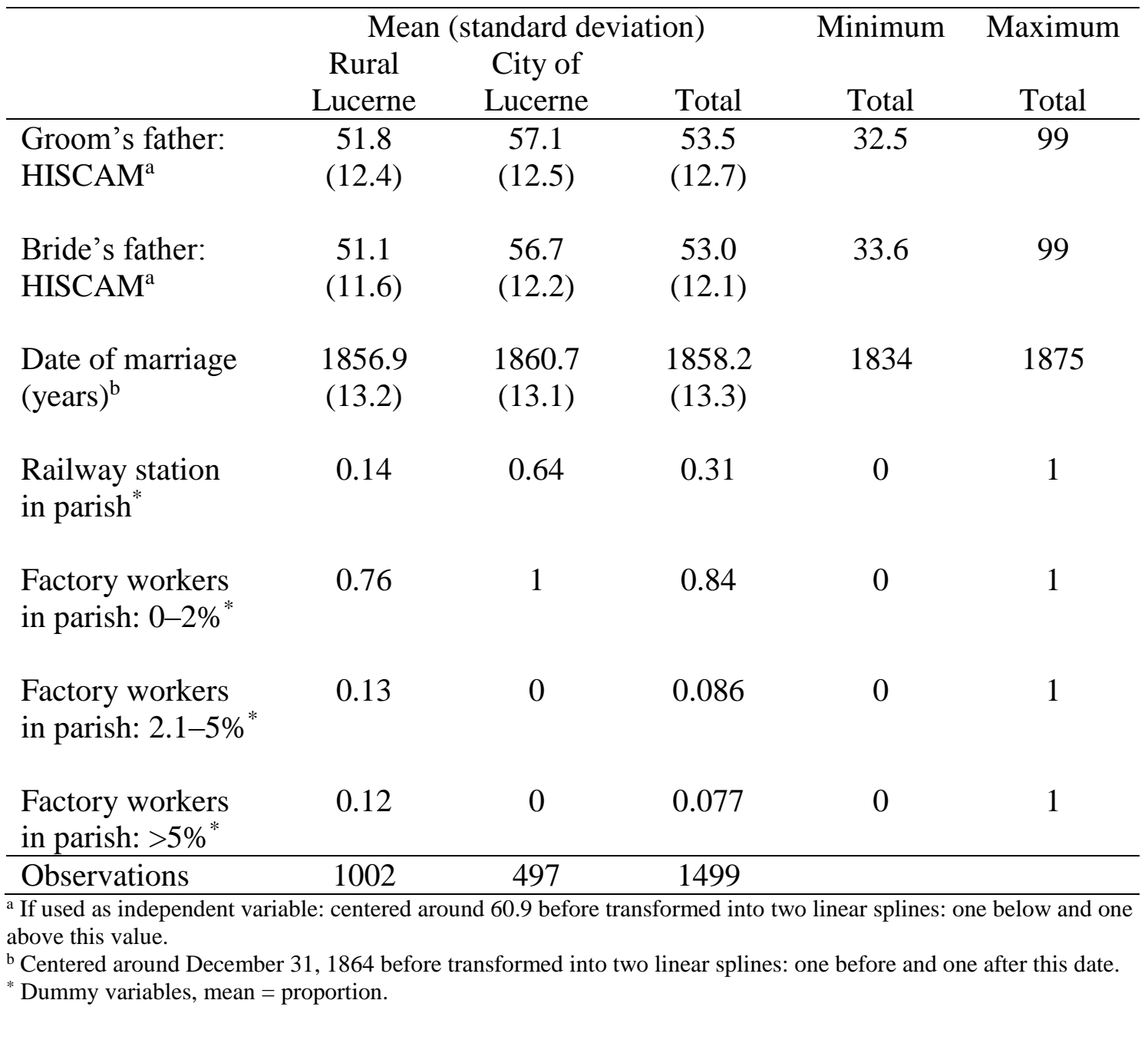


1 Table 2. Time trends: yearly changes of parental status homogamy in rural Lucerne and

2 Lucerne city; linear combinations based on models in Table A1 ${ }^{17}$

\begin{tabular}{|c|c|c|}
\hline \multirow{2}{*}{ Low to medium status: } & Overall trends & Linear splines \\
\hline & & \\
\hline overall (rural) & 0.00385 & \\
\hline 1834-64 (rural) & & $0.00886^{* *}$ \\
\hline $1865-75$ (rural) & & -0.0176 \\
\hline overall (city) & -0.000548 & \\
\hline 1834-64 (city) & & $0.00672^{* * *}$ \\
\hline $1865-75$ (city) & & $-0.0217^{* * *}$ \\
\hline \multicolumn{3}{|l|}{ High status: } \\
\hline overall (rural) & -0.00492 & \\
\hline 1834-64 (rural) & & -0.00315 \\
\hline $1865-75$ (rural) & & -0.0148 \\
\hline overall (city) & $0.00217^{*}$ & \\
\hline 1834-64 (city) & & $0.00929^{* * *}$ \\
\hline $1865-75$ (city) & & $-0.0226^{*}$ \\
\hline$N$ & 1499 & 1499 \\
\hline
\end{tabular}

17 For rural Lucerne, these are merely the interaction effects between the splines for marriage date and fathers' HISCAM, from Table A1. For the city, the table shows the linear combination of those interaction effects and the three-way interactions among year, status and the indicator for the city of Lucerne. 
1 Table A1. Time trends: results from regression models

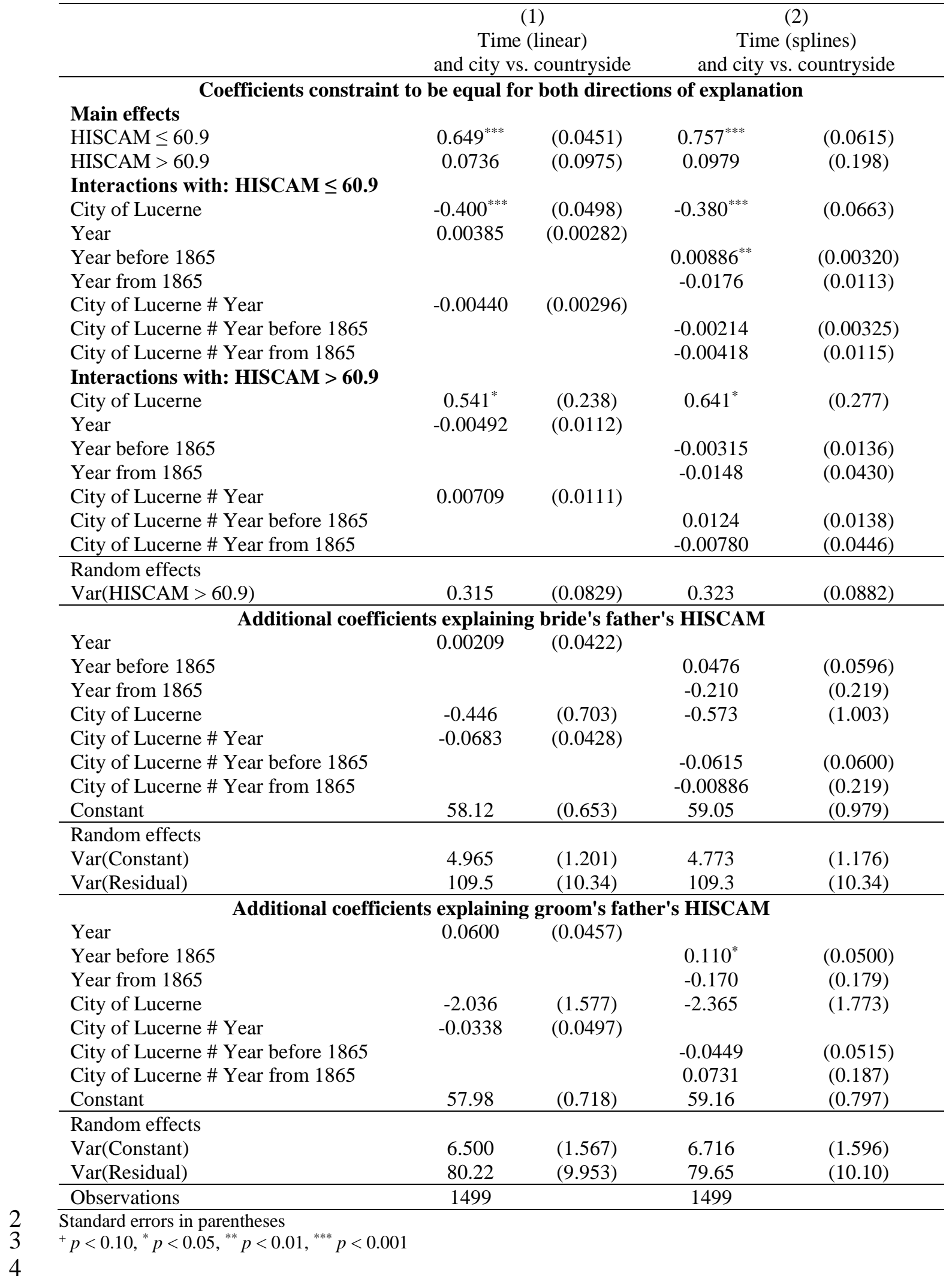


1 Table A2. Railway stations and factory workers: results from regression models

\begin{tabular}{|c|c|c|c|c|c|c|}
\hline & \multicolumn{2}{|c|}{$\begin{array}{c}\text { (1) } \\
\text { Basic: time, rural only }\end{array}$} & \multicolumn{2}{|c|}{$\begin{array}{c}\text { (2) } \\
\text { Basic }+ \\
\text { railway station }\end{array}$} & \multicolumn{2}{|c|}{$\begin{array}{c}\text { (3) } \\
\text { Basic }+ \\
\text { factory workers }\end{array}$} \\
\hline \multicolumn{7}{|c|}{ Coefficients constraint to be equal for both directions of explanation } \\
\hline Main effects & & & & & & \\
\hline HISCAM $\leq 60.9$ & $0.757^{* * *}$ & $(0.0615)$ & $0.745^{* * *}$ & $(0.0673)$ & $0.805^{* * *}$ & $(0.0685)$ \\
\hline HISCAM > 60.9 & 0.109 & $(0.200)$ & 0.113 & $(0.218)$ & 0.153 & $(0.227)$ \\
\hline \multicolumn{7}{|c|}{ Interactions with: HISCAM $\leq 60.9$} \\
\hline Year before 1865 & $0.00880^{* *}$ & $(0.00318)$ & $0.00838^{*}$ & $(0.00341)$ & $0.0107^{* *}$ & $(0.00325)$ \\
\hline Year from 1865 & -0.0176 & $(0.0113)$ & -0.0175 & $(0.0113)$ & -0.0149 & $(0.0109)$ \\
\hline $\begin{array}{l}\text { Railway station in } \\
\text { parish }\end{array}$ & & & 0.0827 & $(0.112)$ & & \\
\hline $\begin{array}{l}\text { Factory workers in } \\
\text { parish: } 2.1-5 \%\end{array}$ & & & & & $-0.161^{+}$ & $(0.0932)$ \\
\hline $\begin{array}{l}\text { Factory workers in } \\
\text { parish: }>5 \%\end{array}$ & & & & & $-0.265^{* *}$ & $(0.0978)$ \\
\hline \multicolumn{7}{|c|}{ Interactions with: HISCAM > 60.9} \\
\hline Year before 1865 & -0.00258 & $(0.0137)$ & -0.00233 & $(0.0148)$ & -0.000596 & $(0.0145)$ \\
\hline Year from 1865 & -0.0165 & $(0.0432)$ & -0.0158 & $(0.0444)$ & -0.00969 & $(0.0415)$ \\
\hline $\begin{array}{l}\text { Railway station in } \\
\text { parish }\end{array}$ & & & -0.0359 & $(0.348)$ & & \\
\hline $\begin{array}{l}\text { Factory workers in } \\
\text { parish: } 2.1-5 \%\end{array}$ & & & & & -0.108 & $(0.433)$ \\
\hline $\begin{array}{l}\text { Factory workers in } \\
\text { parish: }>5 \%\end{array}$ & & & & & -0.811 & $(0.646)$ \\
\hline \multicolumn{7}{|l|}{ Random effects } \\
\hline $\begin{array}{l}\text { Var(HISCAM > } \\
60.9)\end{array}$ & 0.340 & $(0.0952)$ & 0.337 & $(0.0954)$ & 0.449 & $(0.151)$ \\
\hline \multicolumn{7}{|c|}{ Additional coefficients explaining bride's father's HISCAM } \\
\hline Year before 1865 & 0.0468 & $(0.0596)$ & 0.0342 & $(0.0666)$ & 0.0718 & $(0.0660)$ \\
\hline Year from 1865 & -0.211 & $(0.219)$ & -0.212 & $(0.220)$ & -0.203 & $(0.223)$ \\
\hline $\begin{array}{l}\text { Railway station in } \\
\text { parish }\end{array}$ & & & 1.952 & (1.776) & & \\
\hline $\begin{array}{l}\text { Factory workers in } \\
\text { parish: } 2.1-5 \%\end{array}$ & & & & & -1.921 & (1.507) \\
\hline $\begin{array}{l}\text { Factory workers in } \\
\text { parish: }>5 \%\end{array}$ & & & & & -3.060 & (1.929) \\
\hline Constant & 59.04 & $(0.981)$ & 58.70 & $(1.129)$ & 59.70 & $(1.162)$ \\
\hline \multicolumn{7}{|l|}{ Random effects } \\
\hline Var(Constant) & 5.077 & $(1.226)$ & 4.799 & $(1.160)$ & 5.145 & $(1.276)$ \\
\hline Var(Residual) & 105.7 & $(11.21)$ & 105.6 & $(11.23)$ & 105.5 & $(11.27)$ \\
\hline
\end{tabular}

\begin{tabular}{lcccccc} 
Var(Residual) & 105.7 & $(11.21)$ & 105.6 & $(11.23)$ & 105.5 & $(11.27)$ \\
\hline $\begin{array}{l}\text { Additional coefficients explaining groom's father's HISCAM } \\
\text { Year before 1865 }\end{array}$ & $0.109^{*}$ & $(0.0499)$ & $0.110^{*}$ & $(0.0521)$ & $0.151^{* *}$ & $(0.0536)$ \\
Year from 1865 & -0.169 & $(0.180)$ & -0.175 & $(0.181)$ & -0.119 & $(0.177)$ \\
$\begin{array}{l}\text { Railway station in } \\
\text { parish }\end{array}$ & & 0.0311 & $(1.661)$ & & \\
$\begin{array}{l}\text { Factory workers in } \\
\text { parish: 2.1-5\% }\end{array}$ & & & & & $-3.439^{* *}$ & $(1.083)$ \\
$\begin{array}{l}\text { Factory workers in } \\
\text { parish: }>5 \%\end{array}$ & & & & & $-5.966^{* * *}$ & $(1.553)$ \\
Constant & 59.15 & $(0.797)$ & 59.17 & $(0.875)$ & 60.29 & $(0.985)$ \\
\hline $\begin{array}{l}\text { Random effects } \\
\text { Var(Constant) }\end{array}$ & 6.929 & $(1.668)$ & 6.998 & $(1.678)$ & 6.769 & $(1.539)$ \\
Var(Residual) & 72.95 & $(9.130)$ & 72.95 & $(9.127)$ & 71.73 & $(9.190)$ \\
\hline Observations & 1002 & & & & 1002 & \\
\hline
\end{tabular}

2 Standard errors in parentheses

$3+{ }^{+} p<0.10,{ }^{*} p<0.05,{ }^{* *} p<0.01,{ }^{* * *} p<0.001$ 


\section{$1 \quad 8$ Figures}

2 Figure 1. Map of Switzerland, and map showing the selected parishes within the canton

3 of Lucerne. Sources: map of Switzerland: Dufour (1855), reproduced by permission of

4 swisstopo (BA17032); map of Lucerne: Schnider (1996, 48, 261), reproduced by

5 permission of Geoinformation Kanton Luzern; railway lines added according to: Wägli

6 and Jacobi (2010); own shading.

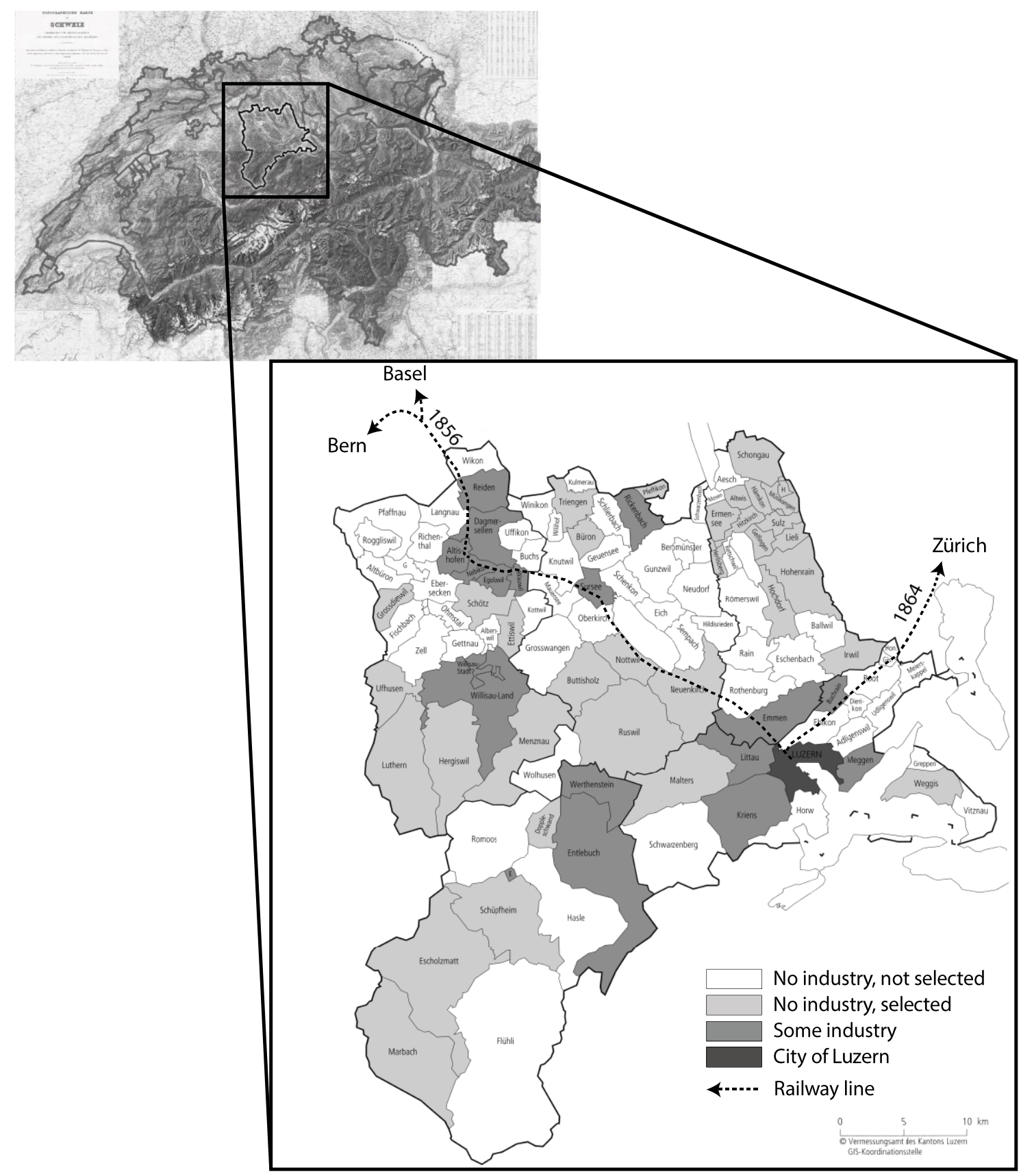


1 Figure 2. Scheme of the combination of the effects on homogamy of modernization and

2 marriage restriction among individuals of (a) low to middle and (b) high social origin.

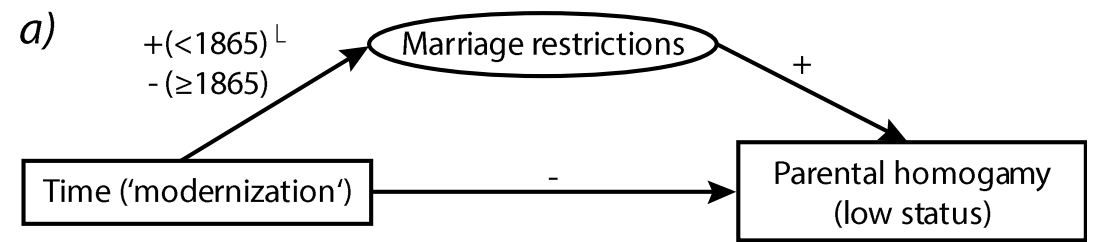

b)

3

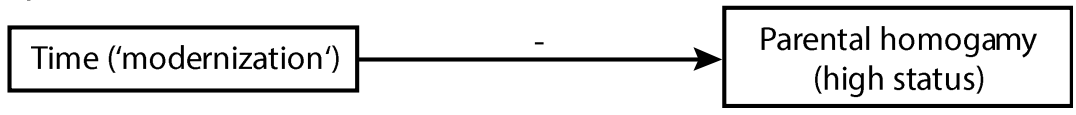

4 Figure 3. Measuring (a) and explaining (b) social homogamy.

a)

Groom's father's HISCAM

Bride's father's HISCAM b)

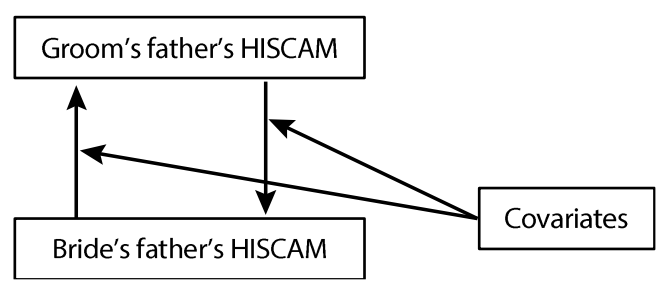

6 Figure 4. Groom's father's and bride's father's status for rural Lucerne and Lucerne

7 city: scatterplots and local polynomial (lpoly) smooth plots; circle sizes are proportional

8 to the prevalence of the status combinations.

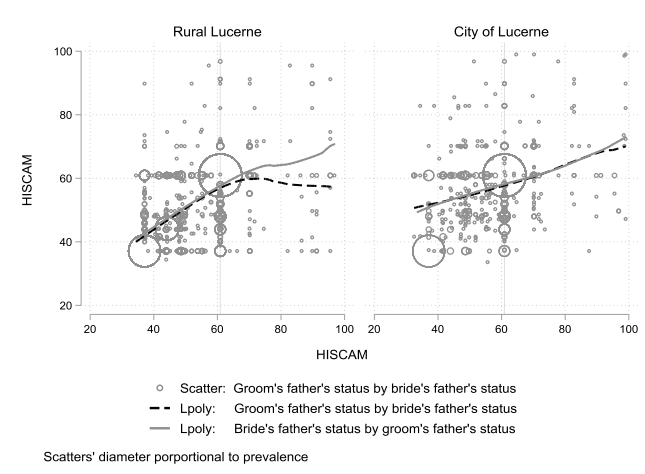


1 Figure 5. City vs. countryside: parental status homogamy by social stratum; average 2 marginal effects based on model 1 in Table A1.

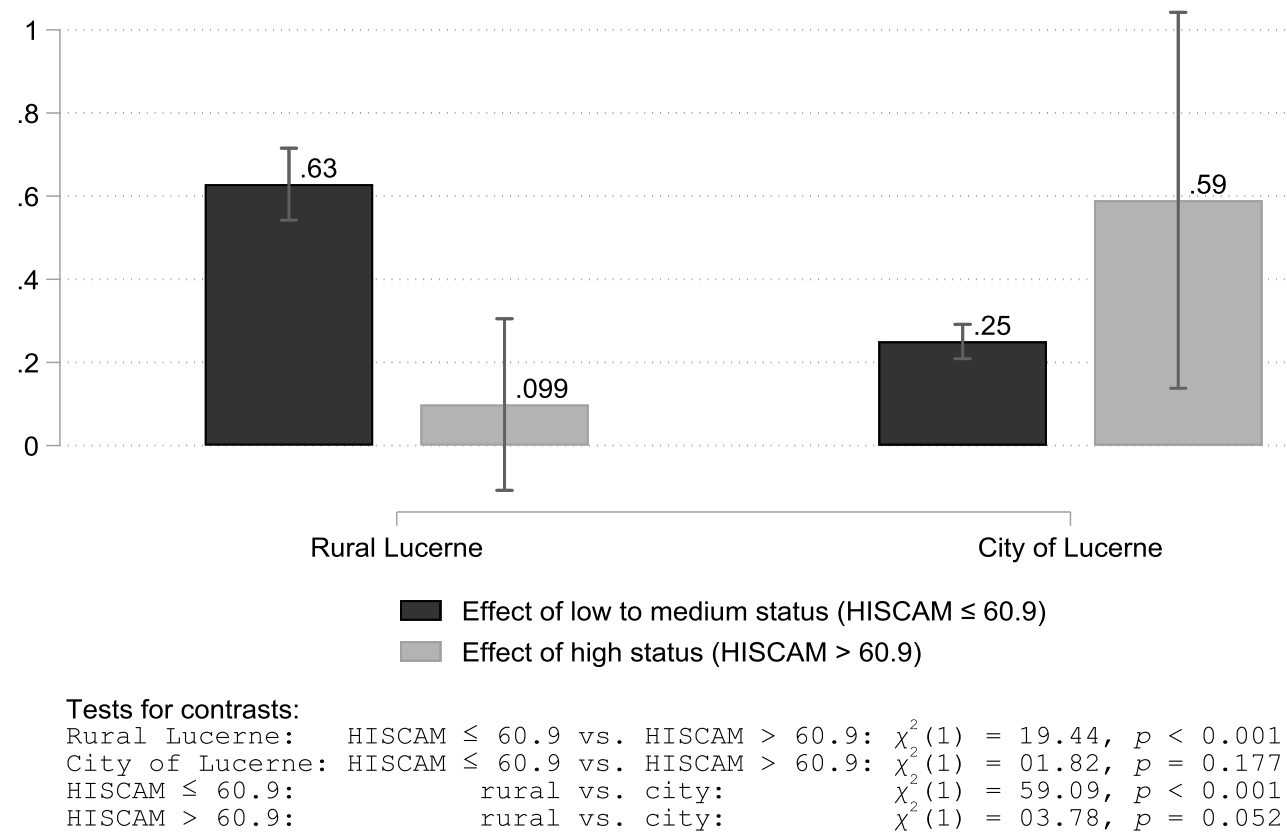

Note: Spikes indicate $95 \%$ confidence intervals. 
1 Figure 6. Time trends: parental status homogamy by date of marriage and social stratum

2 in the city of Lucerne and in the countryside; average marginal effects based on model 2 3 in Table A1.

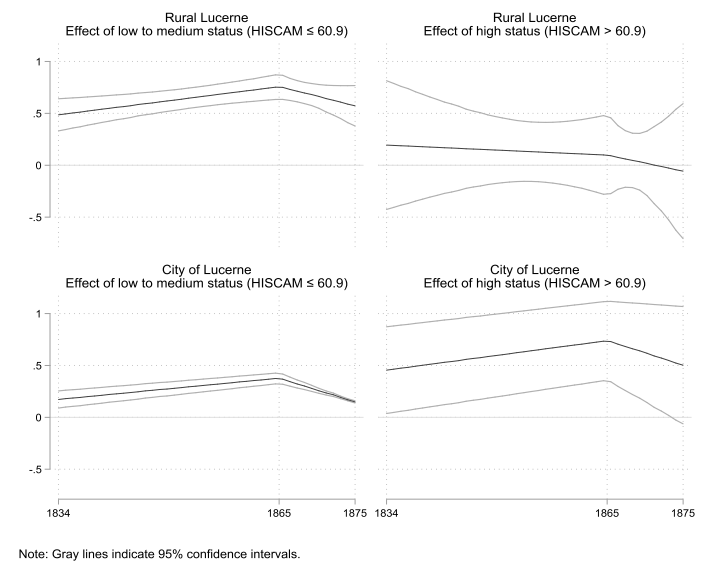


1 Figure 7. Effects on parental status homogamy of railway station in parish, and of 2 proportion of factory workers by social stratum; graphical representation of selected 3 coefficients from model 2 and 3 in Table A2.

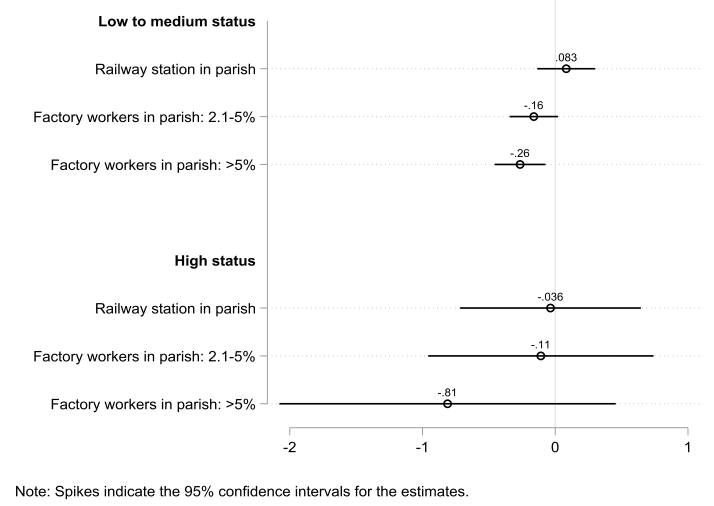

